Review

\title{
Conserved Binding Regions Provide the Clue for Peptide-Based Vaccine Development: A Chemical Perspective
}

\author{
Hernando Curtidor ${ }^{1,2}$, César Reyes ${ }^{1}$, Adriana Bermúdez ${ }^{1,2}$, Magnolia Vanegas ${ }^{1,2}$, \\ Yahson Varela ${ }^{1,3}$ and Manuel E. Patarroyo $1,4, *$ \\ 1 Colombian Institute of Immunology Foundation (FIDIC Nonprofit-Making Organisation), \\ Bogotá 111321, Colombia; hernando.curtidor@urosario.edu.co (H.C.); cmreyessa@unal.edu.co (C.R.); \\ adriana.bermudez@urosario.edu.co (A.B.); magnolia.vanegas@urosario.edu.co (M.V.); \\ yfvarelaq@hotmail.com (Y.V.) \\ 2 School of Medicine and Health Sciences, University of Rosario, Bogotá 111321, Colombia \\ 3 Faculty of Health Sciences, Applied and Environmental Sciences University (UDCA), \\ Bogotá 111321, Colombia \\ 4 Faculty of Medicine, National University of Colombia, Bogotá 111321, Colombia \\ * Correspondence: mepatarr@gmail.com; Tel. +57-1-2225277/Fax: +57-1-3244673 ext. 120
}

Received: 27 October 2017; Accepted: 27 November 2017; Published: 12 December 2017

\begin{abstract}
Synthetic peptides have become invaluable biomedical research and medicinal chemistry tools for studying functional roles, i.e., binding or proteolytic activity, naturally-occurring regions' immunogenicity in proteins and developing therapeutic agents and vaccines. Synthetic peptides can mimic protein sites; their structure and function can be easily modulated by specific amino acid replacement. They have major advantages, i.e., they are cheap, easily-produced and chemically stable, lack infectious and secondary adverse reactions and can induce immune responses via T- and B-cell epitopes. Our group has previously shown that using synthetic peptides and adopting a functional approach has led to identifying Plasmodium falciparum conserved regions binding to host cells. Conserved high activity binding peptides' (cHABPs) physicochemical, structural and immunological characteristics have been taken into account for properly modifying and converting them into highly immunogenic, protection-inducing peptides (mHABPs) in the experimental Aotus monkey model. This article describes stereo-electron and topochemical characteristics regarding major histocompatibility complex (MHC)-mHABP-T-cell receptor (TCR) complex formation. Some mHABPs in this complex inducing long-lasting, protective immunity have been named immune protection-inducing protein structures (IMPIPS), forming the subunit components in chemically synthesized vaccines. This manuscript summarizes this particular field and adds our recent findings concerning intramolecular interactions ( $\mathrm{H}$-bonds or $\pi$-interactions) enabling proper IMPIPS structure as well as the peripheral flanking residues (PFR) to stabilize the MHCII-IMPIPS-TCR interaction, aimed at inducing long-lasting, protective immunological memory.
\end{abstract}

Keywords: synthetic peptides; therapeutics; immunogenicity; malaria vaccine; structure

\section{Introduction}

It has been suggested that acquiring natural immunity against severe clinical malaria in endemic regions [1], protection via immune IgG passive transfer [2,3], immunization (in mice, primates and humans) with live-attenuated sporozoites (Spz) (via mosquito bite, intravenous injection, etc.) [4-10] and immunization with defined antigens (recombinant proteins or peptides) [11-15] can induce a protective immune response against challenge with live Spz, and/or natural or experimental infection, thereby supporting the feasibility of developing effective malarial vaccines. There is no in vitro culture 
system for live-attenuated Spz at present, thereby hindering this methodology's large-scale application using irradiated malaria-infected mosquitoes; multiple mosquito bites do not constitute a proper immunization routine. Some antigens or biological approaches induce short-lived immune responses and the resulting protective immunity is usually species-specific. A completely protective vaccine is still not available, even though different strategies have been followed to date and supposedly promising vaccine candidates have been tested (alone or mixed), making malaria one of the greatest public health challenges [16]. Designing and developing a subunit vaccine (i.e., peptide-based on Spzand merozoite (Mz)-derived antigens) has thus been suggested as a likely alternative approach.

\section{A Synthetic Peptide-Based Vaccine Is Feasible}

It was reported more than 50 years ago that a tobacco mosaic virus protein-derived peptide fragment had been able to induce an antiviral response [17]; Merrifield reported the first synthesis of a tetrapeptide in the same year (1963) and coined the concept of stepwise solid-phase peptide synthesis [18]. This led to many papers being published, describing synthetic peptide use for many applications (Figure 1).

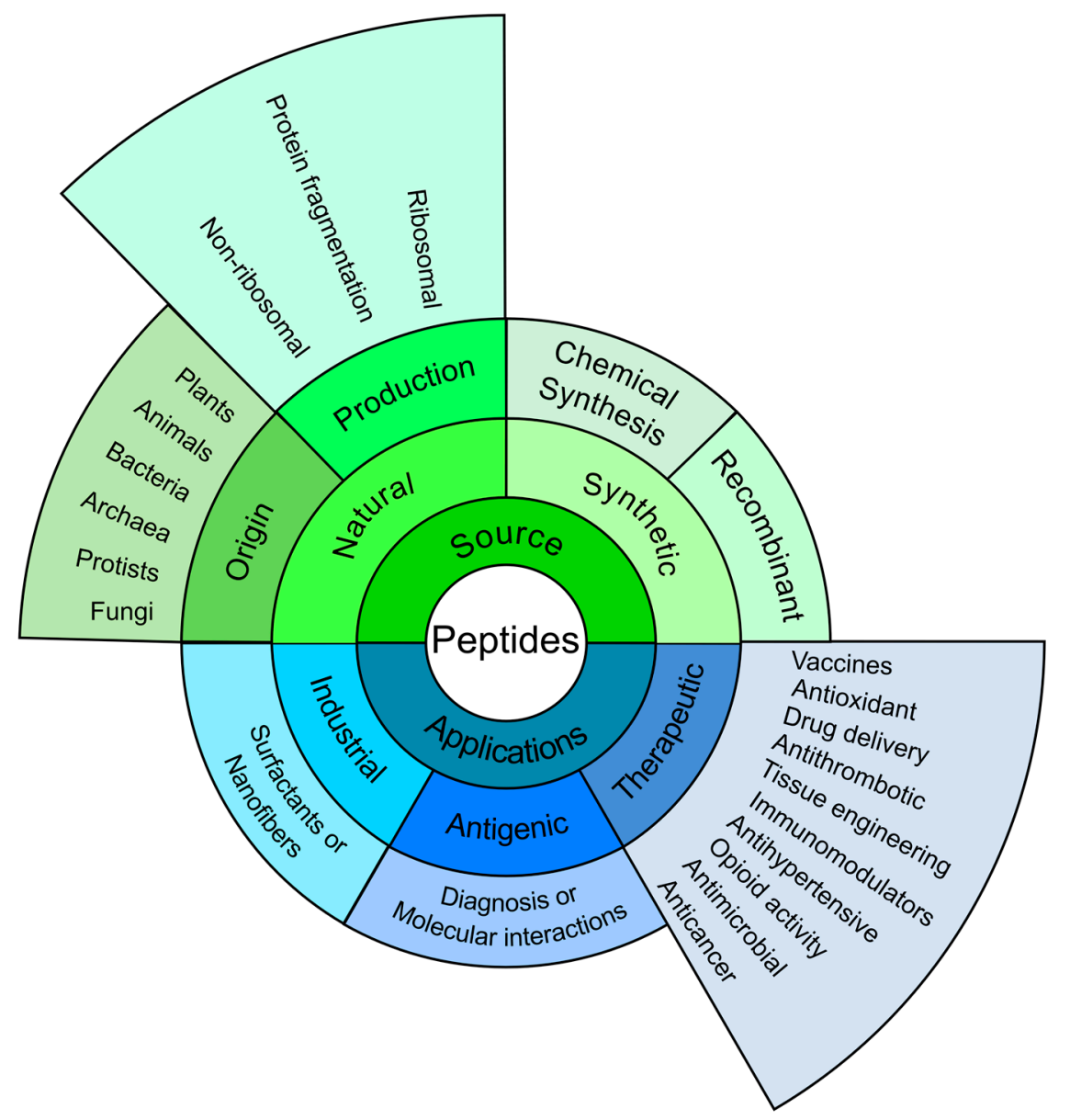

Figure 1. Peptides overview: The figure summarises the main aspects related to peptides: origin, classes and applications. As can be observed, although having some industrial applications [19,20], synthetic peptides are also used as antigens in diagnosing diseases [21,22], studying molecular interactions [23], and identifying pathogens proteins' functional regions [24-26]. However; it is worth highlighting their scope in the vast field of therapeutic applications [27-34].

Remarkably, synthetic peptides can be used for studying the immune response and its nature, as well as identifying $\mathrm{T}$ - and B-cell epitopes or vaccine candidates and their relationship with an 
observed immune response [11,35-40]. It has been shown that using synthetic peptides provides advantages over recombinant fragments; for example, synthetic peptides do not integrate into an immunized host's chromosomes, immune responses are focused on specific epitopes from one or different antigens into one antigenic formulation and an induced protective immune response is sometimes higher than that induced by other antigens, like live-attenuated or killed parasite vaccines $[11,41]$.

Several reports in the 1980s highlighted the success achieved of using synthetic peptides as vaccines against several diseases caused by different types of pathogen and in different models (Table 1). Our group found that immunising Aotus monkeys with a synthetic chimera (SPf66), using circumsporozoite surface protein (PfCSP)-derived immunodominant NANP repeat sequence as spacer $[42,43]$, induced fully-protective immunity in 50\% of them and a similar percentage in human volunteers against experimental challenge with infected erythrocytes $[11,39,44]$. This was the first antimalarial, multi-epitope and multi-stage synthetic vaccine ever developed [11].

Table 1. Synthetic peptides as vaccines.

\begin{tabular}{|c|c|c|c|c|}
\hline Name & Disease & Agent & Model \& Outcome & Ref. \\
\hline & Diphtheria & $\begin{array}{l}\text { Corynebacterium } \\
\text { diphtheriae }\end{array}$ & Guinea pigs became protected & [45] \\
\hline & Foot-and-mouth disease & $\begin{array}{l}\text { Foot-and-mouth disease } \\
\text { virus }\end{array}$ & $\begin{array}{l}\text { Neutralising antibodies induced in rabbits } \\
\text { and guinea pigs }\end{array}$ & [46] \\
\hline & Foot-and-mouth disease & $\begin{array}{l}\text { Foot-and-mouth disease } \\
\text { virus }\end{array}$ & Cattle became protected & {$[47]$} \\
\hline & Malaria & Plasmodium berghei & Mice became protected & [38] \\
\hline & Gastroenteritis & Simian rotavirus & Neutralising antibodies induced in rabbits & [48] \\
\hline & $\begin{array}{l}\text { Acquired immune } \\
\text { deficiency syndrome }\end{array}$ & $\begin{array}{c}\text { Human } \\
\text { immunodeficiency virus }\end{array}$ & Neutralising antibodies induced in rabbits & [49] \\
\hline $\begin{array}{l}\text { First multi-epitope synthetic } \\
\text { antimalarial vaccine }\end{array}$ & Malaria & Plasmodium falciparum & Aotus monkeys became protected & [39] \\
\hline SPf66 & Malaria & Plasmodium falciparum & Humans became protected & [11] \\
\hline SPf66 & Malaria & Plasmodium falciparum & Safe and highly-immunogenic in humans & [50-52] \\
\hline \multirow[t]{4}{*}{ SPf66 } & Malaria & Plasmodium falciparum & $\begin{array}{l}\text { Protective efficacy ( } 30-40 \%) \text { in semi-immune } \\
\text { populations }\end{array}$ & [12,53-55] \\
\hline & $\begin{array}{l}\text { Haemorrhagic enteritis, } \\
\text { Myocarditis }\end{array}$ & Canine parvovirus & Dogs became protected & [56] \\
\hline & Malaria & Plasmodium vivax & $\begin{array}{l}\text { Parasite development in the mosquito was } \\
\text { blocked }\end{array}$ & [57] \\
\hline & Anthrax & Bacillus anthracis & Rabbit became protected & [58] \\
\hline \multirow[t]{2}{*}{ Fusion peptide } & Influenza & Influenza A virus & Mice became protected & [59]. \\
\hline & Swine fever & $\begin{array}{l}\text { Classical swine fever } \\
\text { virus }\end{array}$ & Neutralising antibodies induced in pigs & [60] \\
\hline CIGB-228 & $\begin{array}{l}\text { Cervical intraepithelial } \\
\text { neoplasia }\end{array}$ & Human papilloma virus & Lesion regression and HPV clearance & [61]. \\
\hline IMPIPS & Malaria & Plasmodium falciparum & Aotus monkeys became protected & {$[62,63]$} \\
\hline
\end{tabular}

Several Phase IIb and Phase III clinical trials, showed that SPf66 was safe and highly-immunogenic in humans and protective (30-40\%) in semi-immune populations subject to natural challenge and in several independent randomized controlled trials (Table 1). However, SPf66 efficacy decreased in a trial involving the newborn and infants when delivered through Tanzania's expanded programme of immunization (EPI) [64-66]. We thus decided to stop SPf66 vaccination and focused our efforts during the next 20 years on developing a complete, fully protective, second-generation malaria vaccine.

\section{Adopting a Functional Approach for Vaccine Development}

Plasmodium parasites have a complex life-cycle involving two hosts (humans and Anopheles mosquitoes), three invasive stages (Mz, Spz and ookinete) and three different host cells which are the target for such invasive stages: Mz invade red blood cells (RBC), Spz hepatocytes and ookinetes epithelium midgut cells (Figure 2). Around 80 proteins have been shown to be involved in the invasion of these susceptible cells [67-69]. 


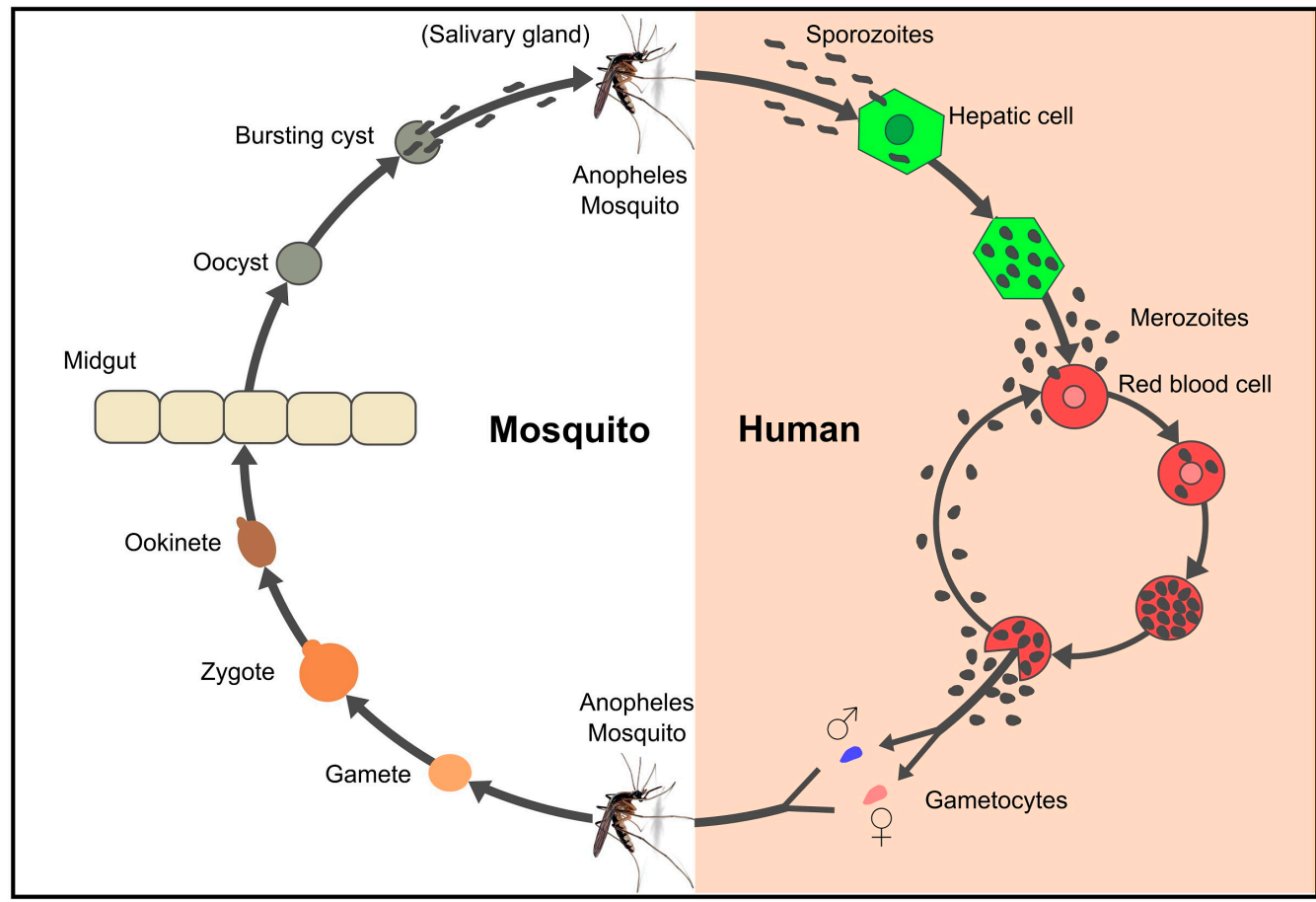

Figure 2. Life cycle of Plasmodium falciparum. Spz entry through the bite of a female Anopheles mosquito begins the Plasmodium spp. life-cycle in humans. Spz travel through the bloodstream to reach and invade liver cells, thereby initiating the pre-erythrocyte cycle [70]. Spz grow and divide within the hepatocytes, producing 10,000-30,000 Mz per invaded hepatocyte, depending on the Plasmodium specie [71]. Once $\mathrm{Mz}$ are released into the bloodstream, each one can invade RBCs in about $45 \mathrm{~s}$. $\mathrm{Mz}$ develop to ring, trophozoite and (48 to $72 \mathrm{~h}$ ) schizont stages inside RBC, producing about $8-32 \mathrm{Mz}$ which can invade new RBC [72]. Some Mz develop into sexual forms called gametes (male and female) which are ingested by a mosquito. Sexual reproduction takes place within a mosquito's midgut where new Spz migrate to the salivary glands to start the parasite's life-cycle all over again [73].

The parasite's life-cycle complexity is just one challenge to be understood in depth, as it has developed different evasion mechanisms, such as protein variation, antigenic polymorphism, altered peptide ligands (APLs), alternative invasion pathways, cryptic epitopes, immunosuppression, immunological smoke-screens and antigen shedding, thereby inducing long- or short-lived non-protective immune responses [74-80]. Repetitive antigens (used erroneously as vaccines) have been targets for strong, but not protective, immune responses. It is believed that repetitive antigens, such as the circumsporozoite (CS) protein amino acid (aa) sequence, acts as an immunological "smoke-screen" helping to evade the immune response [81,82]. All the above has suggested that using antigens (or regions derived therefrom) as targets for natural antigenicity should be avoided when selecting vaccine components.

Successful SPf66 results suggested that peptide length was suitable and that peptide polymerization, increasing peptide (antigen) length, was a good option regarding synthetic vaccine development $[11,12,64,83]$. However, it was also evident that more antigens (subunit components), representing proteins from the main stages in the parasite's life-cycle (Mz and Spz), had to be included to ensure a fully protective, anti-malarial vaccine; however, the question remained how many should be selected and how should this be ascertained?

\section{Subunit Component Selection}

Different approaches have been adopted for selecting the best candidates for use as vaccines. The first antigens (pre-genome era) were whole inactivated/killed parasites [84-88] or were selected 
following the so-called immunological approach, i.e., proteins or their regions recognized by immune sera from adults or infected monkeys. Such epitopes can induce a protective immune response, or are the target for monoclonal antibodies which, in turn, can inhibit asexual blood stage growth in vitro [89-91]. Other antigens were selected for their structural characteristics [92], their location on $\mathrm{Mz}$ or Spz surface, or for playing a critical role in parasite development or $\mathrm{Mz}$ invasion of erythrocytes [93-95]. More recently, data obtained following publication of the Plasmodium falciparum genome (post-genome era), transcriptome and proteome has led to around 80 proteins being identified as key elements in RBC and hepatocyte invasion [67,68,96-100].

While studying SPf66-induced humoral immune response in humans [101,102] and looking for new vaccine candidates $[103,104]$ we were also studying the relationship between Mz proteins and RBC invasion. It was seen that peptides having high RBC binding activity could also inhibit Mz invasion of RBC; remarkably, two out of three Mz protein-derived peptides (included in the SPf66 vaccine) were found [105]. This pivotal observation led to the breakthrough from using the classical immunological approach to searching for vaccine candidates, involving a completely functional approach which we have followed during the last 30 years. Mz- and Spz-derived high activity binding peptides (HABPs) associated with the invasion of both host cell types had to be recognized.

A highly robust, specific, sensitive and well-designed receptor-ligand binding methodology [106-109], was used to recognise functionally-relevant aa sequences in all proteins described as being involved in RBC or hepatocyte binding and invasion. Entire protein sequences were synthesized as sequential 20-mer-long peptides and their ability to bind hepatic cells or RBC was determined. Hill coefficients $\left(n_{H}\right)$, dissociation constants $\left(K_{d}\right)$ and the amount of binding sites were calculated for those having high binding activity (i.e., HABPs), as well as the nature and molecular weight of their receptors [110-112]. Some Mz-derived HABPs inhibited Mz invasion of RBC, suggesting an association with critical parasite functions, such as recognition, rolling, reorientation, gliding and/or attachment and invasion [107,111,113]. Using these peptides as subunit components of an antimalarial vaccine thus gained wide recognition (i.e., highlighting the value of adopting a functional approach).

Such rationale was substantiated by immunising Aotus monkeys with polymeric HABPs and experimentally challenging them with freshly-obtained RBC infected by the highly-infectious Aotus-adapted P. falciparum FVO strain. The apparently disappointing results showed that HABPs having conserved aa sequences (cHABPs) were poorly or non-immunogenic and did not induce any protection in the Aotus monkey model. However, HABPs having variable sequences (vHABPs) could induce a highly strain-specific protective immune response [114-117]. These results agreed with reports showing that antigenic or immunogenic proteins having variable aa sequences had been used as an immunological evasion mechanism (i.e., they induced strain-specific immune protection and repeat aa sequences induced non-protective immune responses) $[76,81,118]$. These results partly explained the systematic failure arising from using complete X-ray-irradiated or genetically-altered parasites, DNA naked encoding specific proteins or complete recombinant proteins, since practically all of them have been seen to have genetic variability in one or several regions [119-121].

BLAST analysis of the aforementioned results regarding all $P$. falciparum strains described to date suggested that $\mathrm{CHABP}$ regions lacking genetic variation or polymorphism in their aa sequences should involve critical biological functions for parasite survival, like maintaining protein folding, acting as ligands during invasion $[113,122]$, have metal $\left(\mathrm{Mg}^{++}, \mathrm{Ca}^{++}\right)$or ATPase binding, enzymatic activity (phospholipase or serine protease), cavity formation, $\mathrm{Ca}^{++}$release, membrane transport and protein export via Plasmodium export element (PEXEL) motifs [113]. This might explain why such sequences are immuno-silent and, therefore, the perfect vaccine target, or in our words, "the malaria parasite's Achilles heel" [123].

Our results showed that the parasite avoids the immune response by using conserved aa sequences to perform critical biological functions. Although these sequences are available for the immune system, they are immunologically silent due to the particular and specific 3D structure they adopt [123,124]. Furthermore, protein 3D studies have shown that parasite cHABPs from the most functionally-relevant 
structures involved in host cell invasion are craftily located far away from highly polymorphic and immunogenic regions to distract the immune response [79].

Based on the altered peptide ligand concept (APL), where some aa replacements modulate the immune response, we decided that conserved functional sequences had to be modified to break the parasite's immunological code of silence, following a clearly established set of rules [77,125]. Genetic control of the immune response had to be taken into consideration as we had been warned long beforehand by analysis of the immune response induced in individuals immunized with SPf66. This data showed an association of low or non-responders with a particular MHC class II allele (HLA-DR $\beta 1 * 0401)$, suggesting imperfect SPf66 vaccine component fit into the MHCII-peptide-T-cell receptor (TCR) trimer complex [101,102], as well as preferential usage of TCR V $\beta 3$ or V $\beta I I$ regions having a similar aa sequence to that of cHABP 1513 included in SPf66.

Non-responsiveness and/or non-protection-inducing ability led to two very relevant characteristics: imperfect fit into MHCII molecules (since it was later shown that cHABP 1513 had high HLA-DR $1 * 0801$ binding capability) and inducing a TCR preferential usage having high aa sequence homology with the $1513 \mathrm{cHABP}$ [126].

Studies based on the elegant description of MHC genetics, function, 3D structure and role in regulating TCR antigen recognition on T-cell membrane [127-129] have opened the way forward for the rational development of vaccines. This has involved identifying antigens recognized by specific MHC molecules able to form stable MHC-peptide-TCR trimer complexes and thus induce a suitable immune response; however, as the human MHC is highly polymorphic, specific antigens and the amount of determinants necessary to overcome MHC restriction [130] have had to be carefully selected to avoid a non-responsive, suppressive or harmful immune response.

Since Aotus monkeys are highly susceptible to human malaria, their immune system molecules are very similar (80-100\% identical) to that of humans and their experimental infection can be treated with antimalarial drugs [131-136] they thus form an ideal experimental model for malaria research. This meant that conserved binding regions in the most relevant proteins involved in parasite-host cell invasion and infection had thus to be identified from a biological point of view and their 3D structure determined from a structural and physicochemical point of view. Converting such key regions (cHABPs) into immune protection-inducing protein structures (IMPIPS) $[63,77,123]$ thus became the driving force behind our logical and rational methodology for vaccine development, using P. falciparum malaria as our prototype disease.

\section{Breaking the Parasite's Immunological Code of Silence}

Different strategies have been proposed for enhancing short peptides' immunogenicity (i.e., natural or synthetic adjuvants or delivery system), such as using carriers [137-140], conjugation with T-helper and B-cell activation proteins [139], identifying cryptic epitopes [141], peptides mimicking native structures (Cys-Cys bond inclusion) [142], peptide elongation [143] and using MHCII peptide binding prediction servers for predicting new epitopes [144]. Most of the above approaches involve modifying peptide or epitope sequences so that MHC molecule and/or peptide-MHC complex binding affinity for TCR molecules becomes increased [145].

The seminal finding which led to us modifying cHABPs arose from the observation that, when the long (40-mer) linear, polymerized SPf66 molecule was synthesized ( 10 KDa), the methionine residue in the 83.1 peptide sequence (YSLFQKEKM*VL) became converted into sulphomethionine due to long-lasting, recurrent deprotection treatment; this did not occur with the 83.1 short monomer (12-mer), having high RBC binding capability [107]. This particular residue modification changed peptide polarity and its 3D structure. It thus became clear that cHABP physicochemical and structural characteristics would have to be modified to render them highly immunogenic and protection-inducing. HABP analogues were synthesized and tested in binding assays to identify "critical" binding $\mathrm{RBC}$ residues in an attempt to break the parasite's immunological code of silence associated with functionally relevant cHABP sequences, since methionine was a critical binding residue in cHABP 83.1 
(glycine scanning) $[111,115,146,147]$. As in a previous report determining the particular contribution to antigen-antibody interaction of each residue in an antigen sequence [148], we found that some residues could be "critical" for cell binding [111,115,146,147].

When modifying critical binding residues in cHABP sequences, for increasing their immune response [149], we found that some mHABPs did not induce any immune response or protection after experimental challenge while others induced high antibody titers (short-lived or long-lived) but did not induce any protective immune response $[115,116,150]$. Interestingly, some mHABP sequences induced high, long-lived antibody titers, conferring complete, sterile protection against experimental challenge in Aotus monkeys [115,116,151]. The results for cHABP derived from the same or different proteins [114,146,152,153], after analyzing many synthesized peptides $(\sim 40,000)$ and a suitable/statistically significant amount of monkey immunization assays revealed that critical binding residues had to be replaced by others having similar mass, volume and surface, but opposite polarity (i.e., $F$ by $R$ and vice versa $R ; W \leftrightarrow Y ; L \leftrightarrow H ; P \leftrightarrow D, N ; M, L \leftrightarrow K ; A \leftrightarrow S ; C \leftrightarrow T$ or $V \leftrightarrow Q, E$ ), one of the fundamental rules in synthetic vaccine development [111,151,154,155].

${ }^{1} \mathrm{H}-\mathrm{NMR}$ (500 or $600 \mathrm{MHz}$ ) determination of three-dimensional (3D) structures and cHABP and mHABP binding to purified HLA-DR $\beta 1$ human molecules highlighted the fact that careful cHABP sequence changes induced structural modifications thereby allowing better mHABPs-MHC interaction and induced protection for Aotus monkey against experimental challenge with the highly infectious P. falciparum FVO strain $[155,156]$.

Once questions related to antigen selection and how to increase immunogenicity and protection-inducing capacity had been resolved; the next challenge lay in identifying the mechanism by which mHABPs could induce a protective immune response. As expected, increased mHABP immunogenic properties were closely related to their 3D structure and their interaction with $\mathrm{MHCII}$ and TRC molecules. All this was related to mHABP sequences' intimate physicochemical features: length, charge, volume, secondary structure, aa side chain orientation, intra-molecular interactions and peripheral flanking residue (PFR) secondary structure.

\section{Chemical Features to Be Taken into Account in Vaccine Development}

\subsection{Immune System Molecules' 3D Structure}

MHC molecules were so named by Gorer and Snell's pioneering work due to their prominent role in histocompatibility acceptance or tissue and/or organ rejection during transplants [157,158]. Located on antigen-presenting cell surface, they are also responsible for a host adaptive immune response by presenting short derived peptides to the TCR [159]. An in-depth understanding of the MHC-antigen-TCR triad is thus needed for inducing antibodies against foreign intruders and disease control.

The MHC gene encodes three different molecules (class I, II and III (Figure 3A); MHC class I and II play relevant roles in antigen presentation while MHC class III encodes complement system molecules and inflammatory cytokines, including tumor necrosis factor (TNF) [160-162].

MHC class I consists of two non-covalently linked $\alpha$ - and $\beta 2$-microglobulin $(\beta 2 \mathrm{~m})$ chains, the $\alpha$-chain being highly polymorphic and the $\beta 2 \mathrm{~m}$-chain conserved. This MHC molecule binds 8-10 aa-long peptides (either self- or non-self) in endoplasmic reticulum lumen. The MHCI-peptide complex (Figure 3B) travels to the cell surface to present intracellular antigens to the CD ${ }^{+}$cytotoxic cell TCR after binding, involving several molecules, such as transporter associated with antigen processing (TAP), tapasin, calreticulin, calnexin and the thiol oxidoreductase of the endoplasmic reticulum (Erp57) [163-165]. 
A. Major Histocompatibility Complex Gene

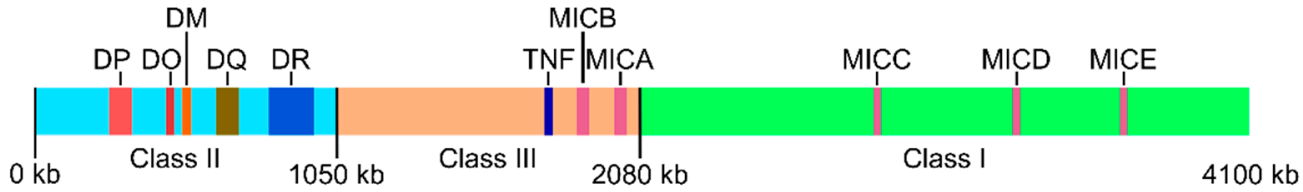

B. Major Histocompatibility Complex Class I (MHC-I)
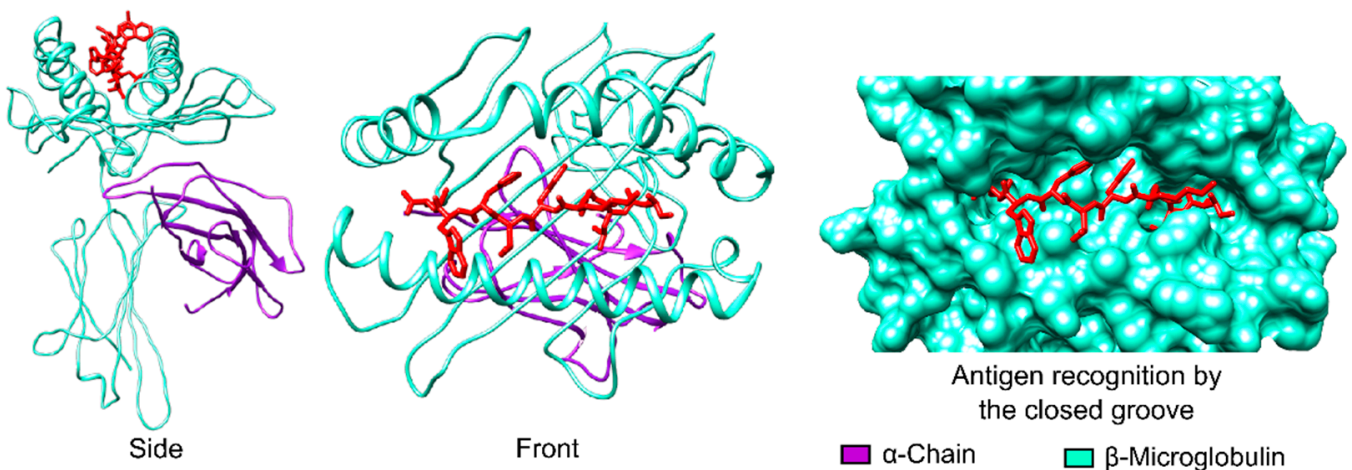

C.

Major Histocompatibility Complex Class II (MHC-II)
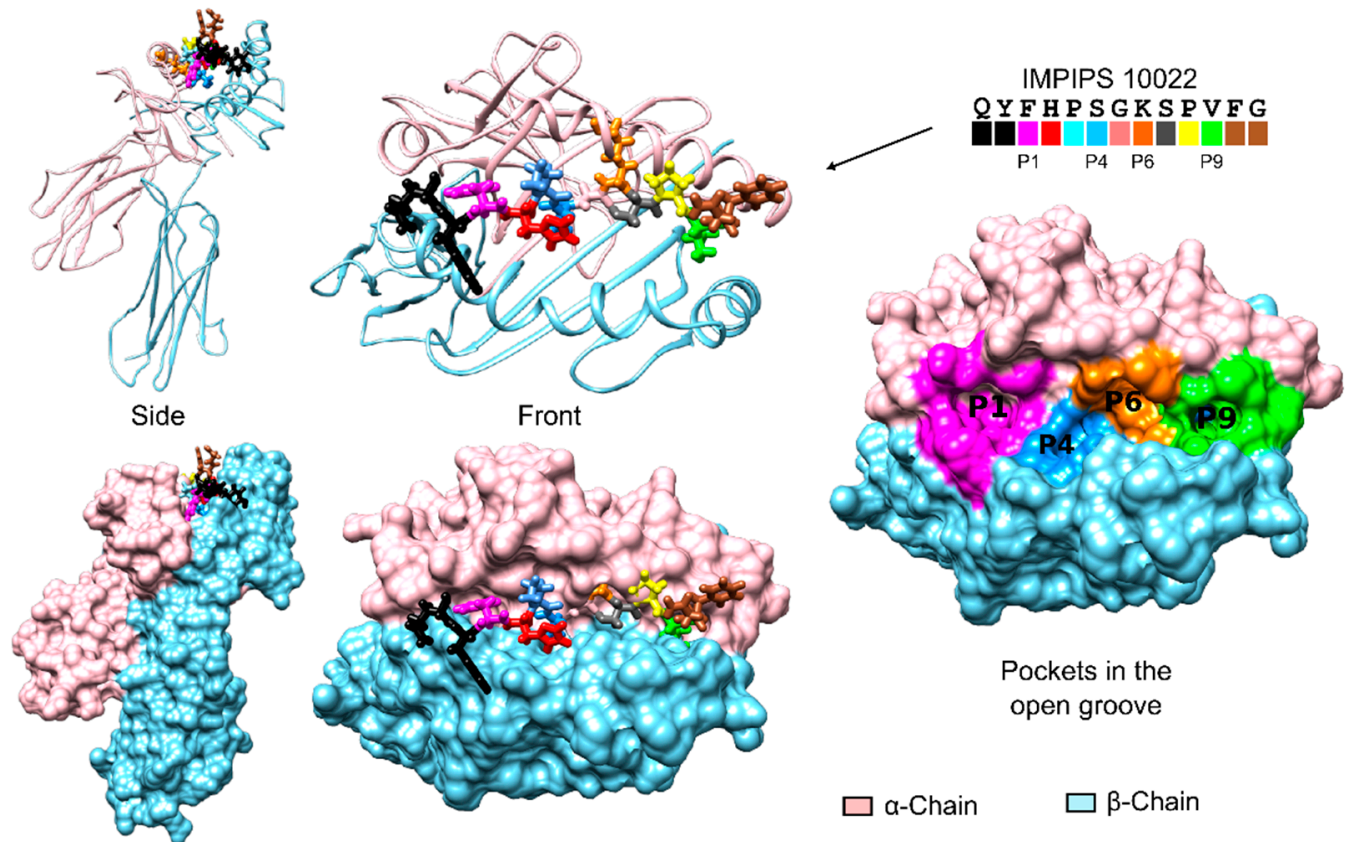

Pockets in the open groove

a-Chain $\square \beta$-Chain

Figure 3. Major histocompatibility complex. (A) Schematic representation of the gene encoding the three MHC classes, with the most important proteins roughly located; (B) Major histocompatibility complex class (MHC) I ribbon and surface structure (based on PDB code 5MEP) displaying the $\alpha$-chain, the $\beta$-microglobulin as well as the closed groove for peptide antigen recognition [166]; (C) MHC class II ribbon and surface structure (based on PDB code 1A6A [167] displaying the $\alpha$ - and $\beta$-chains and the open groove for peptide antigen (IMPIPS 10022, sequence and colour code given) recognition [168] coloured according to the same color code for pockets P1, P4, P6 and P9.

MHC class II molecules are normally found only on professional antigen-presenting cells, like macrophages, B-cells and dendritic cells (DCs). They bind processed antigens (resulting from protein acidic-enzymatic cleavage) in the endosomal-lysosomal compartment with the help of a 
non-classical class II molecule (HLA-DM) to become externalized on cell surface for recognition by TCRs on CD4 ${ }^{+}$T-lymphocytes $[165,169]$. T-cell memory and effector cell differentiation are mediated by MHC class II; thus memory cells become activated when the same antigen/infection enters an organism and the immune response is triggered [169]. Therefore, a complete understanding of antigen presentation is required for vaccine-development; structural MHC class II features have thus to be established since it is known that an antibody-mediated malaria immune response is highly associated with class II molecules [170-173]. Very elegant structural analysis has shown that multifunctional MHCII molecules are formed by two non-covalently associated and cell membrane-anchored proteins [127-131]. The peptide groove or binding region (PBR) in distal $\alpha 1$ (almost conserved) and $\beta 1$ domains (polymorphic) is formed by a pair of opposite $\alpha$-helices on a floor of eight antiparallel $\beta$-strands (Figure 3C).

The PBR is open at both ends and can bind 13-25 residue-long peptides; however, the interaction involves only 9 residues by means of four major pockets (numbered relative to the largest HLA-DR1 pocket 1 (P1), accommodating and stabilizing the peptide side chains of the residues located in positions (p) p1, p4, p6 and p9 (Figure 3C). Pocket polymorphism explains class II allele specificities; several combinations of the aforementioned four aa are permitted, since all four pockets can accommodate a wide variety of side chains. An antigen's overall specificity depends on the four residues' proper fit into such pockets; the peptide backbone should have a zig-zag like structure, similar to a polyproline type II conformation and, since the immune response relies on a suitable MHCII-antigen-TCR interaction, antigen recognition is restricted by the characteristic sequence of each chain forming the heterodimeric MHC II molecule [174,175].

We found that $\mathrm{Mz}$ apical membrane antigen 1 (AMA-1) cHABP 4313 ( ${ }^{134}$ DAEVAGTQYRL PSGKCPVFG ${ }^{153}$ )-derived mHABP 10022.43 (DAEVAGTQYFP1 ${ }^{1} \mathrm{HSP}^{4} \mathrm{GK}^{\mathrm{P}} \mathrm{SPVP}^{\mathrm{P}} \mathrm{FG}$ ) having two left-handed PPII $\mathrm{L}_{\mathrm{L}}$ regions in p1-p4 and p6-p9, experimentally bound to HLA-DR $\beta 1^{*} 0302$, HLA-DR $\beta 1^{*} 0701$ and HLA-DR $\beta 1^{*} 0301$ purified molecules. Such structural conformation allowed mHABP 10022.43 an almost perfect fit into HLA-DR $\beta 1^{*} 0302$ (Figure 3C), $[176,177]$. These alleles had a dimorphic sequence in P1 allowing different residues to fit into it. Such observations were also made for P4, P6 and $\mathrm{P}$, meaning that MHCII-peptide interaction (and thus the immune response) was dependent on the stereo-electron characteristics of the residues forming genetically-determined pockets [62,178]. MHC class II architecture thus implies that peptides must be at least fifteen amino acids long to induce the appropriate immune response regarding any peptide-based vaccine.

\subsection{Charge and Volume}

Stable interactions in the MHC-peptide-TCR ternary complex are needed to trigger an appropriate immune response and (like any other physical phenomenon) it has its own features and requirements, charge and volume being crucial for such interaction. Every antigen aa interaction with MHC and TCR molecules has to maximize attraction forces, as well as minimize repulsion forces. There are ideal values concerning the maximum volume accepted (related to steric hindrance) and electron characteristics (according to attracting forces' formation) regarding every position. Figure 4 shows HLA-DR $\beta 1^{*} 03^{\prime} \mathrm{P} 6$ where smaller aa elicit weak interaction forces whilst bigger ones do not fit into this relatively small pocket. The interaction forces for aa having the proper volume will depend on the side chain charge. Each human MHCII molecule has conserved and specific electrostatic characteristics, correlated with the peptide sequence with which they interact [179]. Protein (MHC and TCR)-peptide interactions can thus be seen as the total sum of interactions between aa and such interactions are ruled by the specific characteristics of each of the 20-mer aa and their possible combinations.

A theoretical analysis of aa interactions (200 possible aa pairs) based on three simple premises (opposite charges attract while similar charges repel, convex fits to concave and similar hydrophobicity works together), based on size, charge and hydropathy indices for protein structure analysis, revealed the prevalence of opposite-charged residue pairs, along with unexpected ones, like positive-neutral pairs being more compatible than negative-neutral pairs [180]. Another study, 
using discrete molecular dynamics (DMD), evaluated peptide-protein recognition in a set of ten protein-peptide systems. A two-step binding mechanism model was proposed which included random peptide-protein region collisions to form a metastable "encounter complex", the second step being peptide docking on protein surface which required conformational receptor change to reach a native-like binding state. These results suggested that electrostatic interactions played an important role in peptide-protein recognition and highlighted the importance of appropriately charged residues in peptides used in vaccine design [181,182].

A study involving quantum chemical topological (QCT) calculation of Becke-3 parameter-Lee-Yang-Parr charges (polarisation-consistent (pc) double- $\zeta$ plus polarization basis set (B3LYP/apc-1)) located protonated ( $\mathrm{R}$, $\mathrm{K}$ and $\mathrm{H}$ ) and deprotonated (D and $\mathrm{E}$ ) residue charges [183,184]. Comparing average atomic charges for these five residues (over a thousand conformations for both charged and neutral aa) revealed that $81 \%$ of negative charges were located on the aspartic acid side chain while $88 \%$ were on the glutamic side chain, whilst the entire charge for the protonated ones was located on the side chain. This led to the conclusion that the peptide backbone was not greatly influenced by side chain charge due to methylene group insulator effect in these five aa, as well as when charge was spread over several atoms (e.g., H and R) [183].

Studies regarding the role of specific peptide residues binding to MHCII-PBR during antigen presentation have shown this complex system's sensitivity to small changes in aa charge, volume and orientation or regarding peptide structure [185]. An aa peptide-MHC binding prediction-derived similarity matrix has shown that the most unfavorable effect of a single residue substitution results from substituting residues having opposite charges [186].

For example, our MHC-DR studies have shown that DR8 P6 (deep and negatively charged) allowed positively-charged residue binding in the MSP-1 ${ }^{38-55}$ peptide (a SPf66 sequence extension) and stimulated human T-cell response [11,80]. We found that P4 in DR4 and DR3 was also important for determining DR-bound peptide side chain specificity, binding negatively-charged side chains and having an alternative binding register [80].

Recent in-depth structural analysis has shown that any malaria vaccine component identified as highly immunogenic and protection-inducing (following challenge in immunized Aotus monkeys) can be readily used in humans without further modification [187]. Since Aotus MHCII 3D structure has not yet been described, we used well-known HLA-DR $\beta 1^{*}$ crystallographic structures to model monkey alleles. By comparing electrostatic potentials and volume calculations we were able to establish differences between human and monkey MHCII molecules, concluding that such differences were not great enough to prevent any vaccine candidate component developed from the Aotus model being readily used on humans [187].

The forgoing means that aa in positions p1, p4, p6 and p9 (for any peptide-based vaccine) must be carefully chosen to maximise the interaction with MHC-II molecules and induce an appropriate immune response.

\subsection{Peptide-Antigen Length}

Even though both MHCI and MCHII molecules bind antigens to present them to the TCR and trigger an immune response, there are huge structural differences between these two molecules' PBR which must be taken into account during vaccine development. MHCI molecules comprise a closed binding site, allowing them to accommodate 8-10 residue-long peptides, while MHCII molecules can present much longer peptides due to their open-ended PBR [175,188]. Peptide elongation (greater than 9-mer long) can increase HLA-antigen affinity (optimal 18-20 aa peptide length); however, the effect becomes negative beyond this point, being associated with enzyme degradation [143,189].

We found that the distance of the nine aa fitting into the PBR groove was actually more important than the amount of aa in a peptide. Our studies of MHCII molecules, ${ }^{1} \mathrm{H}-\mathrm{NMR}$ antigen structure and antigen-interacting active site characteristics concluded that any antigen must have a $26.5 \pm 1.5 \AA$ distance between the first and ninth aa fitting into the PBR [62]. 


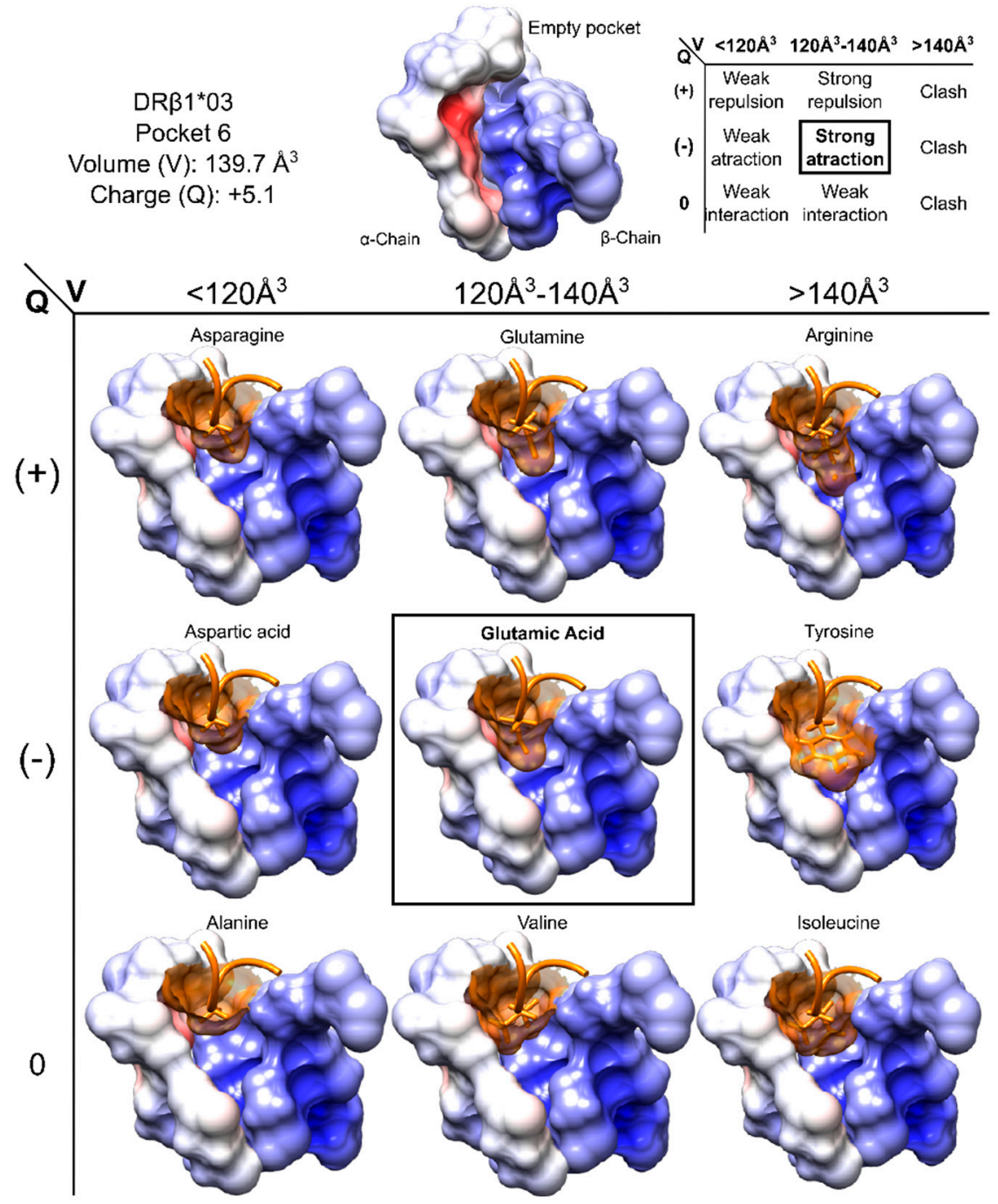

Figure 4. Pocket volume and charge showing aa having different volumes and charge fitting into HLA-DR $\beta 1^{*} 03$ P6. Pocket characteristics and interactions are summarised at the top of the Figure, while the surface structures of aa occupying P6 are shown at the bottom. P6 surface is coloured according to its electrostatic potential set from $-3 \mathrm{kT} / \mathrm{e}$ (negatively charged, red) to $3 \mathrm{kT} / \mathrm{e}$ (positively charged, blue). Figure based and adapted from [187]. Reproduced with permission from Patarroyo ME, Biochem. Biophys. Res. Commun.; published by Elsevier, 2017.

\subsection{Polyproline as Preferred Secondary Structure}

Antigen-interacting MHCII groove characteristics imply that a proper interaction between MHCII and an immunogenic peptide arises from appropriate antigen conformation. Two decades ago it was found that secondary structure of an antigenic (haemagglutinin A, HA)-derived peptide bound to HLA-DR1 had similar structure to that of a polyproline type II (PPII $)$ left-handed helix [190,191]; since then, many studies with experimental immunogens in mice, and others with the human antigen-HLA-DR complex, have reached the same conclusion.

The PPII $_{L}$ helix, having three residues per turn (3.12 Å per residue), results in a considerably extended helical structure which commonly occurs in globular proteins [192-194]. It has a trans isomer for the peptide bonds, a left-handed helix, no hydrogen bonds and $\phi=-75 \pm 25^{\circ}$ and $\psi=145 \pm 25^{\circ}$ dihedral angles. $\mathrm{P}, \mathrm{Q}$ and $\mathrm{D}$ are common residues in $\mathrm{PPII}_{\mathrm{L}}$ conformations, accompanied by some aliphatic residues ( $G, A$ and $L$ ), also having high propensities for left-handed polyproline II helix formation [195]. Typical PPII $L$ CD spectra in water are characterized by a negative band around 
200-205 $\mathrm{nm}$ and a weak positive band at 217-225 $\mathrm{nm}[196,197]$. Due to its importance in protein-protein and peptide-protein recognition, it has been proposed that $\mathrm{PPII}_{\mathrm{L}}$ should be regarded as being equally important as classical $\alpha$-helix, $\beta$-sheet and $\beta$-turn secondary structures $[198,199]$.

Our group has shown that mHABPs having total or partial polyproline II-like left-handed (PPIIL) helixes establishing H-bond $(\sim 7-11)$ interactions with specific residues in MHCII are highly immunogenic protection-inducers or are very high, long-lasting, antibody-inducers [62,200]. Peptides must thus have PPIIL-like secondary structure to fit perfectly into MHC-II molecules and trigger a protective immune response.

\subsection{Amino Acid Side chain Orientation}

Thinking about protein or peptide secondary and tertiary structures usually concerns phi $(\phi)$ and psi $(\psi)$ backbone angles; however, for a given aa having fixed $\phi$ and $\psi$ angles, there is another very important (yet underestimated) angle known as chi1 $\left(\chi^{1}\right)$ (except for glycine, alanine and proline), defined as the dihedral angle involving rotation around the $C \alpha-C \beta$ bond. This is the angle greatly determining a peptide or protein's entire side chain orientation [201,202]. The $\chi^{1}$ variation of a given aa regarding a peptide-antigen implies a change in its side chain orientation, thereby directly affecting interaction with either the MHCII or TCR molecules, leading to a change in the complex's affinity and/or stability [178].

After an in-depth examination of 61 globular proteins in the search for a relationship between side chain orientation and secondary structure, McGregor et al. found that $\chi^{1}$ had a trimodal distribution in globular proteins adopting a trans (to the amide group, $\chi^{1}$ around $180^{\circ}$ ), gauche $e^{+}$(trans to the carboxyl group, $\chi^{1}$ around $300^{\circ}$ ) or gauche (trans to the $\alpha$-hydrogen, $\chi^{1}$ around $60^{\circ}$ ) orientation [203]. The preference was found to be for the gauche rotamer due to the steric clash between $\mathrm{C} \gamma$ and the backbone in the other two rotamers, and almost-full exclusion of the gauche $e^{-}$rotamer for the $\alpha$-helix due to $(i, i-3)$ steric clashes [203]. Later on, 70 polypeptides' aa rotamericity (defined as the percentage of residues in the $\pm 20^{\circ}$ expected rotamer values interval) was evaluated by Schrauber et al. [204] when studying side chain conformation and deviation from expected orientation. The study gave $5-30 \%$ frequency for this deviation $\left( \pm 20^{\circ}\right)$ depending on the aa, and that such rotamericity depended on secondary structure, backbone torsions and tertiary packing requirements (from non-accessible or internal regions). Their results contradicted the idea that protein interiors are relaxed, proving that globular proteins' aa side chains are actually strained in some regions, due to preferred whole protein stability [204].

It was known that protein folding involved a loss of entropy, explained by a folded protein's decreased degrees of freedom compared to those for an unfolded one [205]. Very elegant research by Doig et al. [206] evaluated conformational entropy changes in aa side chains due to protein folding. They calculated the mean of such entropy changes per side chain, using several sets of results, and found that Boltzmann's equation gave a $T \Delta S_{\text {conf }}-0.95 \mathrm{kcal} / \mathrm{mol}$ per residue mean value at $300 \mathrm{~K}$ and a $T \Delta S_{\text {conf }}-0.46 \mathrm{kcal} / \mathrm{mol}$ per bond mean value or rotable $\chi$ angle. Taking differences between states into account, they established a $-4.37 \mathrm{kcal} / \mathrm{mol}$ per residue mean value as the absolute entropy-change (TS). This value contrasted with a $-0.6 \mathrm{kcal} / \mathrm{mol}$ per rotor mean value at $300 \mathrm{~K}$ when considering fusion entropies for some organic compounds which are used as the model for entropy changes in protein folding $[207,208]$. This study showed the considerable importance of changes in side chain conformational entropy, consensus value being $\sim-1 \mathrm{kcal} / \mathrm{mol}$ per residue regarding protein folding or $\sim-0.5 \mathrm{kcal} / \mathrm{mol}$ per rotamer, implying a huge loss of conformational entropy due just to folding [206].

Our group recently reviewed findings regarding the $\chi 1$ angle's effect on the immune behaviour of 20-mer mHABP vaccine candidates [178]. ${ }^{1} \mathrm{H}-\mathrm{NMR} 3 \mathrm{D}$ structures of a set/mixture of peptides having different immunological activities were established and compared to X-ray crystallographic 3D coordinates of different antigens in the PDB-database. This study concluded that a gauche ${ }^{+}$orientation for a residue in $\mathrm{p} 3$ fitting into PBR P3 was critical when mHABPs were used in immunization mixtures. 
It was suggested that this structural feature avoided competition suppression or blocking caused by the mHABP mixture's presentation, due to proper orientation with the corresponding TCR complementary determining region (CDR). It was also found that the residue in $\mathrm{p} 7$ fitting into PBR P7 had to have gauche $^{+}$orientation for inducing fully-protective immunity and long-lasting antibody memory [178]. Thus correct orientation of p3 fitting into PBR P3 and p7 fitting into PBR P7 is essential for residues' proper interaction with the corresponding TCR CDR region.

\subsection{Hydrogen Bonds and Intramolecular $\pi$-Interactions}

Interactions in and between aa are no different from some other attractive or repulsive forces and complete understanding of them is required, since these forces directly influence a given protein or peptide's structural conformation [209,210]. Hydrogen bonds (H-bonds) are known to be one of the most ancient and have been identified as being one of the strongest non-covalent forces; they are responsible for water's unique characteristics and are one of the cornerstones of life on earth [211]. As well as being one of the strongest non-covalent forces, $\mathrm{H}$-bonds, along with electrostatic attractions, van der Waals forces and $\pi$-interactions, are attractive forces, while steric hindrance and electrostatic repulsions are repulsive ones [212-216].

Backbone H-bond contribution to protein stability was controversial for authors believing that H-bonds were destabilizing forces (since intra-peptide H-bond formation breaks peptide-water H-bonds) [217,218]. Nevertheless, others showed that backbone H-bonds actually stabilized proteins, given short poly-Ala peptides' observed $\alpha$-helix propensity at low temperatures $[219,220]$, that buried H-bond disruption destabilized proteins more than a solvent-exposed H-bond could [221] and that environment-dependent H-bonds played a pivotal role in protein folding [182,212].

$\mathrm{H}$-bonds are one of the pillars of protein structure (as recognized today); they are a well-recognized factor in helix $\left(\alpha-, \pi\right.$ - and $\left.3_{10}\right), \beta$-sheet and most $\beta$-turn formation, as well as other protein conformation components $[210,212]$. H-bonds in proteins and peptides are usually (but not exclusively) established between the carboxyl group's oxygen from one residue and the amide hydrogen from another residue [212]. There are several other H-bond-like forms involving polar aa side chains; all of them are directly involved in protein structure stabilization and biological function, recognition and protein-protein interaction [222].

H-bonds' essential role in protein structure and in immune responses has become evident, since T-cell epitopes' total retro-inversion (D-aa) has been seen to have very low MHC binding capability and this was non-immunogenic [223]. We have found that specifically replacing L-aa with D-aa in MSP-1-derived HABP 1513 binding motif did not reduce its binding activity, although its secondary structure became distorted, and that D-analogues were less suitable for T-cell stimulation [224-226]. By contrast, some D-aa replacements (one at a time) in MSP-1-derived HABP 1585 produce D-analogues having improved resistance against proteolytic degradation and higher binding activity than that the cognate peptide. Interestingly, a D-analogue was able to induce protective immune response in Aotus monkey model, suggesting that $\alpha$-carbon chiral transformation is a critical target for structural modulation of the immune response [227]. This would suggests that D-aa are useful for protecting D-analogue peptides from proteolysis and should be taken into account in peptide-based vaccine design. Further studies are needed for determining the precise steps to be followed for residue replacement and peptide design.

On the other hand, our group's structural data showed that cHABPs (identical to their recombinant counterparts) mediated receptor-ligand interactions by forming part of H-bond-stabilised channels or troughs and were located far from or opposite to highly polymorphic regions, suggesting an immune escape mechanism $[79,228]$. It was found that cHABPs became highly immunogenic and sterile immunity inducers in the Aotus experimental model when aa establishing H-bonds with own aa, with those from other cHABPs or binding to host cells were modified [77,229-231].

Merozoite surface protein 2 (MSP-2)-derived cHABP $4044\left({ }^{21} \mathrm{KNESKYSNTFINNAYNMSIR}^{40}\right)$ bound to HLA-DR molecules but did not induce antibodies against $P$. falciparum or protection against 
experimental challenge in Aotus monkeys, while P4-24112 mHABP induced very high antibody titres and complete protection in $66 \%$ of immunized Aotus carrying the HLA-DR $\beta 1^{*} 0403$ allele [232]. Molecular modelling of mHABP 24112 and docking its structure into HLA-DR $\beta 1^{*} 0401$ showed the spontaneous formation of $7 \mathrm{H}$-bonds between its backbone atoms and HLA-DR aa and 3 more with TCR CDR3 $\beta$ [232]. A similar result was found for circumsporozoite protein (CSP)-derived cHABP 4383 ( ${ }^{68}$ NSRSLGENDDGNNEDNEKLR ${ }^{87}$ ) [233]; however, it did not bind to any of the HLA-DR $\beta 1^{*}$ molecules tested here, while mHABP analogue 25608 bound to HLA-DR $\beta 1^{*} 0401$, inducing a very high immune protection-inducing response [234]. Molecular modelling and docking showed the spontaneous formation of $12 \mathrm{H}$-bonds when the 25608.37 conformer was superimposed onto HLA-DR $\beta 1 * 0422$ [234].

Cation- $\pi$ interactions involving electrostatic attraction between aromatic rings (quadrupole created by the $\pi$-electron cloud) and a monopole (positively-charged groups) are also one of the most important interactions involved in molecular recognition, catalytic mechanisms and structural biology [216,235-238]. Sunner et al. made the seminal observation [239] that potassium ions $\left(\mathrm{K}^{+}\right)$in gas-phase preferentially bound to benzene rather than water and established an axial structure by ion-quadrupole and ion-induced dipole attraction; this stimulated thought concerning the nature of cation- $\pi$ interactions [216,240]. Impressive work by Burley and Petsko [241-244] measured, defined and established the importance of protein $\pi$-interactions and their impact on tertiary structure. A significant finding stated that an average of $60 \%$ of globular proteins' aa aromatic side chains were present, at least in aromatic pairs (aro-aro interaction), and $80 \%$ of them formed clusters of three or more interacting aromatic residues (named $\pi-\pi$ interaction). They also described aromatic side chain (F, $\mathrm{W}$ and $\mathrm{Y}$ ) interaction with positively-charged aa (K, R, N, $\mathrm{Q}$ and $\mathrm{H})$ (cation- $\pi$ interaction), as well as oxygen and sulphur atoms interaction with aromatic rings in proteins. Studies with benzene and aa $\mathrm{F}, \mathrm{W}$ and $\mathrm{Y}$ showed this interaction to be an electrostatic effect involving cations and aromatic rings' quadrupole moment and also that the cation-aromatic interaction could compete with water in solvating cations [240]. This work, together with a study showing that cyclophane aromatic rings recognised a positive charge and that cation- $\pi$-cation complex stability (intrinsically repulsive) was largely dependent on the local environment, led to the effect being termed an "ion-dipole" interaction [216].

An average $9.5 \mathrm{kcal} / \mathrm{mol}$ stabilisation energy and edge-anion geometry for this interaction was found using benzene, phenol and indole interacting with formate to mimic interactions between aromatic and anionic aa and second order Møller-Plesset perturbation theory (MP2) calculations. A rapid search of selected PDB entries gave an over-representation of nearly-planar geometry, accompanied by under-representation of axial geometry for anionic-aromatic interacting residues, thereby supporting this finding [245]. Later on it was showed that anion- $\pi$ force geometry seemed to be related to ring electron density since the anion was located at or near the ring centroid for an electron-deficient aromatic system (F) (similar to the cation- $\pi$ complex). By contrast, the anion tended to be located at the edge of the ring for an electron-rich $\pi$-system $(\mathrm{Y})$ interacting with ring plane hydrogen atoms. A lone electron pair from the anion can interact with a non-bonding $\pi$-orbital in such a way as to provide intermediate geometry (known as a $\sigma$-type complex) [246].

An additional stabilising force involves $\pi$-systems (known as XH- $\pi$ interaction); this has been described between methylene groups (-CH2-) (initially belonging to proline but extended to any $\mathrm{X}-\mathrm{H}$ group) and peptide and protein $\pi$-orbitals, following observations of phenol-benzene and ammonia-benzene complexes in gas-phase [247]. Such force was defined as being a kind of hydrogen bond operating between a soft acid XH and a soft base $\pi$-system (not limited to aromatic moieties); it was studied from a supramolecular point of view, as was its impact on crystallographic systems [248].

A special case regarding $\mathrm{XH}-\pi$ interaction concerns a proline and an aromatic residue, this being critical for $\mathrm{Y}$ and $\mathrm{W}$ over $\mathrm{F}$, due to additional electron density on the ring. This is due to proline's unique role in protein folding, where an aromatic residue's proximity to proline induces a conformational change from cis- to trans-proline. The particular non-covalent force's nature has been described 
regarding local and tertiary structure, in protein-protein interactions as well as protein assemblies [249]. Kumar and Balaji's [250] data-mining in two protein structure datasets determined $\mathrm{CH}-\pi$ features involving aa prevalence, propensities and location. Despite all these non-covalent forces being "weak", they cannot be ignored since they are present in a protein or peptide in huge amounts so their final effect is comparable to that of covalent bonds [251].

Our group found that thrombospondin-related anonymous protein (TRAP)-derived cHABP 3287/89 ( ${ }^{241}$ TASCGVWDEWSPCSVTCGKGGTRSRK $\left.{ }^{265}\right)$ formed part of a $\beta$-sheet (A) structure, typical in thrombospondin-related (TSR) domains. It established multiple H-bonds with the backbone and side chain of aa located in the anti-parallel $\beta$-strand (B) structure. Stacked planar cationic guanidinium groups $(\mathrm{R})$ and aromatic groups $(\mathrm{W})$ were stabilized by multiple cationic- $\pi$ interactions forming a continuous positively-charged surface containing a $20 \AA$ A-long groove-like structure, supposedly to receive negatively-charged ligands, such as heparin and heparan sulphates [252].

Our group recently published findings regarding the correlation between non-covalent forces' presence (or absence) and the immunological behavior of several peptides used as vaccine candidates (Figure 5) [253]. The study concluded that intramolecular $\pi$-interactions and H-bonds in the PBR prevented PPIIL formation and their perfect fit into MHC class II molecules therefore induced different immune responses or none at all. These peptides became non-immunogenic and non-protection inducers when there was Aro residue upstream or downstream of any proline, completely distorting $\mathrm{PPII}_{\mathrm{L}}$ conformation. Special care has thus to be taken into account when designing vaccine components involving $\pi$ - $\mathrm{CH}$ interactions, as well as $\pi-\pi, \pi$-cationic, $\pi$-anionic, $\pi$-interactions and $\pi$-s interactions.

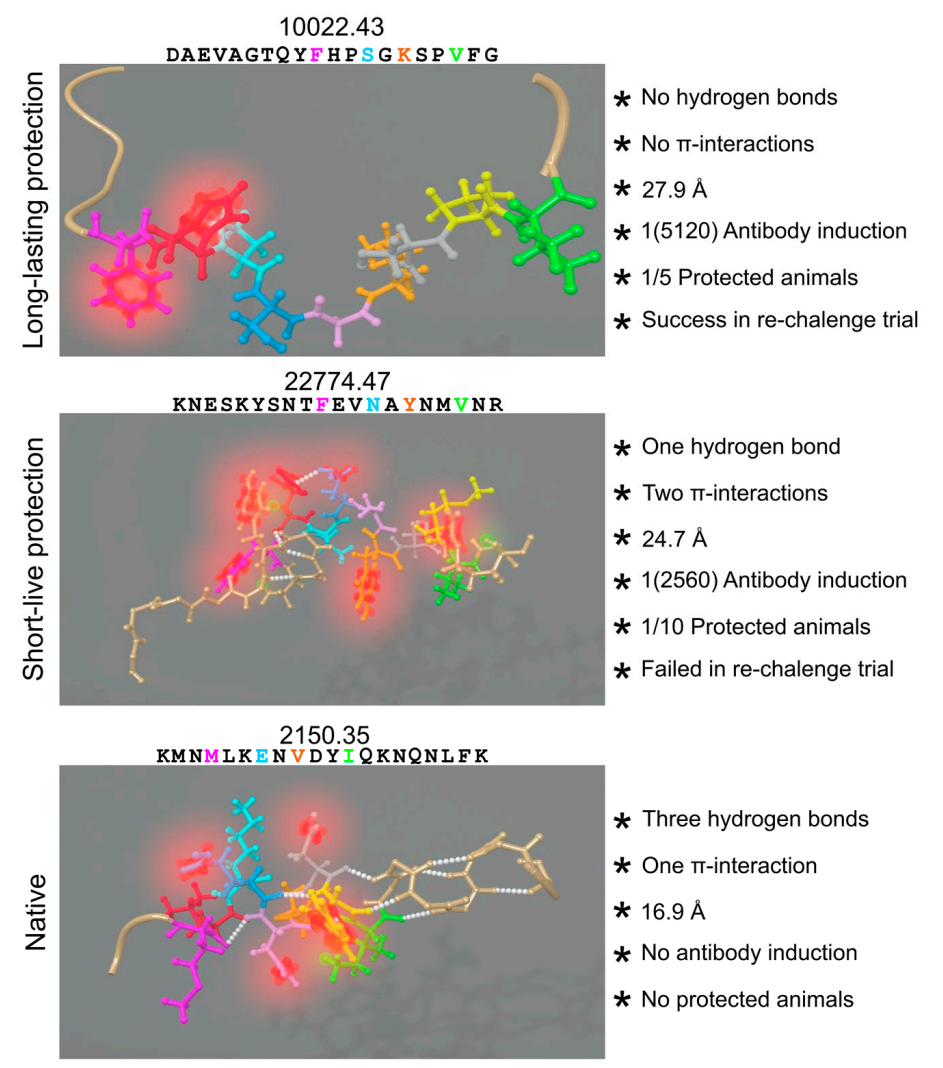

Figure 5. Intramolecular forces' influence: the peptide'sequence and 3D-structure is shown on the left, represented by balls and sticks. Residues, fitting into HLA-DR $\beta$ PBR coloured the same as in Figure 3: $\mathrm{H}$-bonds in white spheres, $\pi$-systems in blurred red and interacting hydrogens in blurred green. Structural and immunogenic features of the nine residues from cHABPs and mHABPs interacting with the PBR are shown on the right. Figure based and adapted from [253]. Reproduced with permission from Patarroyo ME, Biochem. Biophys. Res. Commun.; published by Elsevier, 2017. 


\section{Peripheral Flanking Residues (PFR)}

MHC recognition of peptides is not limited to the residues fitting into the PBR groove but also to the residues located before and after this important region, since this can influence MHC-peptide interactions, TCR recognition and antigen presentation and/or processing. Over the last two decades, several groups have proposed that these peripheral flanking residues (PFR) are crucial for inducing MHC-antigen-TCR complex formation and activity [254-256].

Nelson et al. established HEL 52-61 as the single minimal epitope capable of interacting with murine MHCII I-Ak molecule while studying the immune response driven by hen egg white lysozyme antigen (HEL) [257-260]. Furthermore, antigen-MHCII complex stability (measured by this complex's stability during SDS/PAGE assays) became remarkably increased by adding residues to either end of the HEL 52-61 sequence, as did binding strength (affinity in competition assays). This led to proposing that, while HEL 52-61 contained the residues responsible for immunodominance, the PBR flanking residues were also needed at the ends of the antigen to make the additional contacts necessary for complex stabilization. When peptides containing HEL 52-61 were used for measuring peptide-MHCII complex lifespan it became clear that antigen-presenting cells (APCs) discriminated between antigen-MHCII complexes, as shown by differences arising as time elapsed. The study also suggested that peptide binding strength in the PBR was determined by the aa in $\mathrm{p} 1$ and backbone contacts made by N-terminal PFR [258].

Interestingly, Carson et al. [261] found a stronger T-cell response to antigens (including PFRs) when working with peptides (including the HEL 52-61 immunodominant epitope) and assessing direct mouse T-cell TCR recognition of PFR. These results highlighted PFRs' immunological significance and implications (negative or positive) for immuno-regulation, peptide-based immunotherapy or vaccine development, since PFRs could hinder or unmask epitopes, thereby making them immunologically silent or more accessible to the immune response [261,262].

Based on the previous results, Godkin et al. investigated PFR preferences and whether such preferences were related to antigen processing events [263]. A pool of natural and synthetic peptides was thus constructed and exposed to several HLA-DR molecules to evaluate binding affinities, aa preference in different peripheral positions and TCR recognition. A preference for acidic residues at the antigen's N-terminal as well as for basic residues at the antigen's C-terminal was found and the results showed that such preferences were not related to antigen origin or MHC class II allele family.

Recent studies have shown PFRs' intimate relationship with conformational stability, PFR length with increased binding affinity and how their N- and C-termini affect TCR binding ability and $\mathrm{CD} 4+\mathrm{T}$-cell activation and response as well as T-cell repertoire composition, thus suggesting novel applications regarding CD4+ T-cell peptide vaccine development and diagnostics $[254,264,265]$.

Our recent findings involving ${ }^{1} \mathrm{H}-\mathrm{NMR}$ structural analysis and physico-chemical features regarding the effects of peripheral flanking residues on peptide-based malaria vaccine development [266] have demonstrated that $-\mathrm{p} 2$ (N-terminus) and p10 (C-Terminus) directly influence the immunological behavior of 20 mer-long peptides when used as vaccine candidates. MHCII' F51 $\alpha$, A52 $\alpha$, S53 $\alpha$, F54 $\alpha$ and V85 $\beta$ were the main contacts residues for the aa located in $-\mathrm{p} 2$, whilst MHCII' A68 $\alpha, \mathrm{N} 69 \alpha$, I72 $\alpha, D 57 \beta$, W61 $\beta$ and L67 $\beta$ were the main aa contacting p10. These contacts supported well-studied $\mathrm{N}$-terminal preference for acidic aa and $\mathrm{C}$-terminal preference for basic aa regarding every antigen for proper immune response triggering. These differences enabled differentiating between three functionally-relevant groups: those inducing long-lasting protective memory, short-lived protective memory or non-protection-inducing but high antibody level producers.

Our group's studies ranging beyond N- or C-terminal flanking regions' aa preference for any peptide vaccine candidate are currently geared to finding whether such regions have a preferred secondary structure. Several vaccine candidates' two flanking regions have elicited the same 3D-structure (Figure 6, submitted data): the N-terminal peripheral region pointing downwards towards the $\mathrm{MHCII}$ and the $\mathrm{C}$-terminal peripheral region pointing upwards towards the TCR. On-going analysis 
concerns both peripheral flanking regions' secondary structure preference; a specific $\beta$-turn in the $\mathrm{N}$-terminal section has been established so far (submitted data).
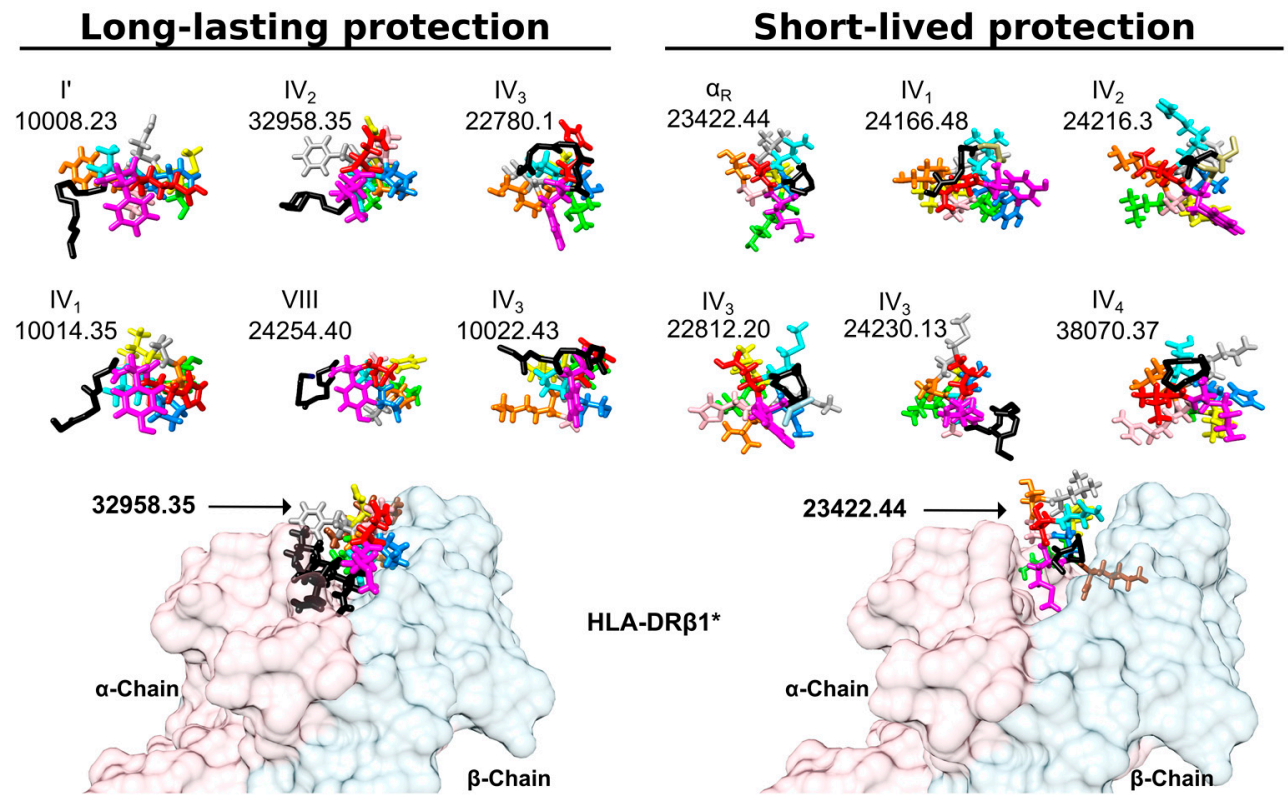

Figure 6. PFR beta structure: the front view shows long-lasting protective and short-live protection inducers. The colour code is the same as that used in Figure 3. Black sticks highlight the backbone of $\mathrm{N}$-terminal peripheral region residues forming $\beta$-turn or $\alpha$-helixes. Note that most structures were left-hand orientated suggesting an interaction with the HLA-DR $\alpha$-chain to collaborate in stabilising this complex. Also note the total absence of the most frequent $\beta$-turn types, such as I, II and II'.

The idea behind the aforementioned search was that MHCII-peptide-TCR complex formation leads to the PBR's nine aa making contact with both proteins (MHC and TCR), and residues located before and after this region, implying their semi-conserved structure due to well-known MHCII-TCR architecture and these two regions' high importance, as recognized by several research groups during the last two decades.

\section{Concluding Remarks}

Synthetic peptides can be used for many functions since they have a single tremendous advantage over other biological resources in that they are chemically defined. Different sequences having different properties can be combined, their structures can be easily modulated or refined by aa replacement and biological function can be mimicked, inhibited or increased [267]. Such aspects can be exploited in a subunit-synthetic peptide-based vaccine approach. We have found that synthetic peptides having conserved $P$. falciparum protein sequences fulfilling different biological functions have been non-immunogenic or protection-inducing against experimental challenge in the Aotus monkey model. However, careful aa changes in cHABP sequences have improved peptide affinity for MHCII molecules and converted them into immunogenic protection-inducers in the Aotus monkey model. Replacing aa must consider each native conserved (cHABP) sequence's stereo and physiochemical characteristics regarding their modified analogue (mHABP) sequences and MHCII PBR sequences (Figure 7).

The following precepts must be observed in subunit vaccine development (i.e., IMPIPS design): $26.5 \pm 1.5 \AA$ is the ideal distance between the first (p1) and ninth (p9) aa of the peptide region fitting into the PBR (nb, intra H-bonds and intra $\pi$-interactions must be avoided); aa volume and charge when replacing p4, p6 and p9 residues must be selected according to the pockets' sequence in each 
PBR; modified peptides (mHABP) must have a polyproline II-like (PPIIL) structure and their backbone $\mathrm{O}$ and $\mathrm{N}$ atoms orientated to establish H-bonds with PBR residues; $\mathrm{p} 3$ and $\mathrm{p} 7$ residues must have p3 $\chi^{1}$, and $\mathrm{p} 7 \chi^{1}$ angle gauche ${ }^{+}$orientation, allowing appropriate rotamer orientation to interact with TCR residues; and N-terminus PFR outside the PBR must have specific $\beta$-turn structures.

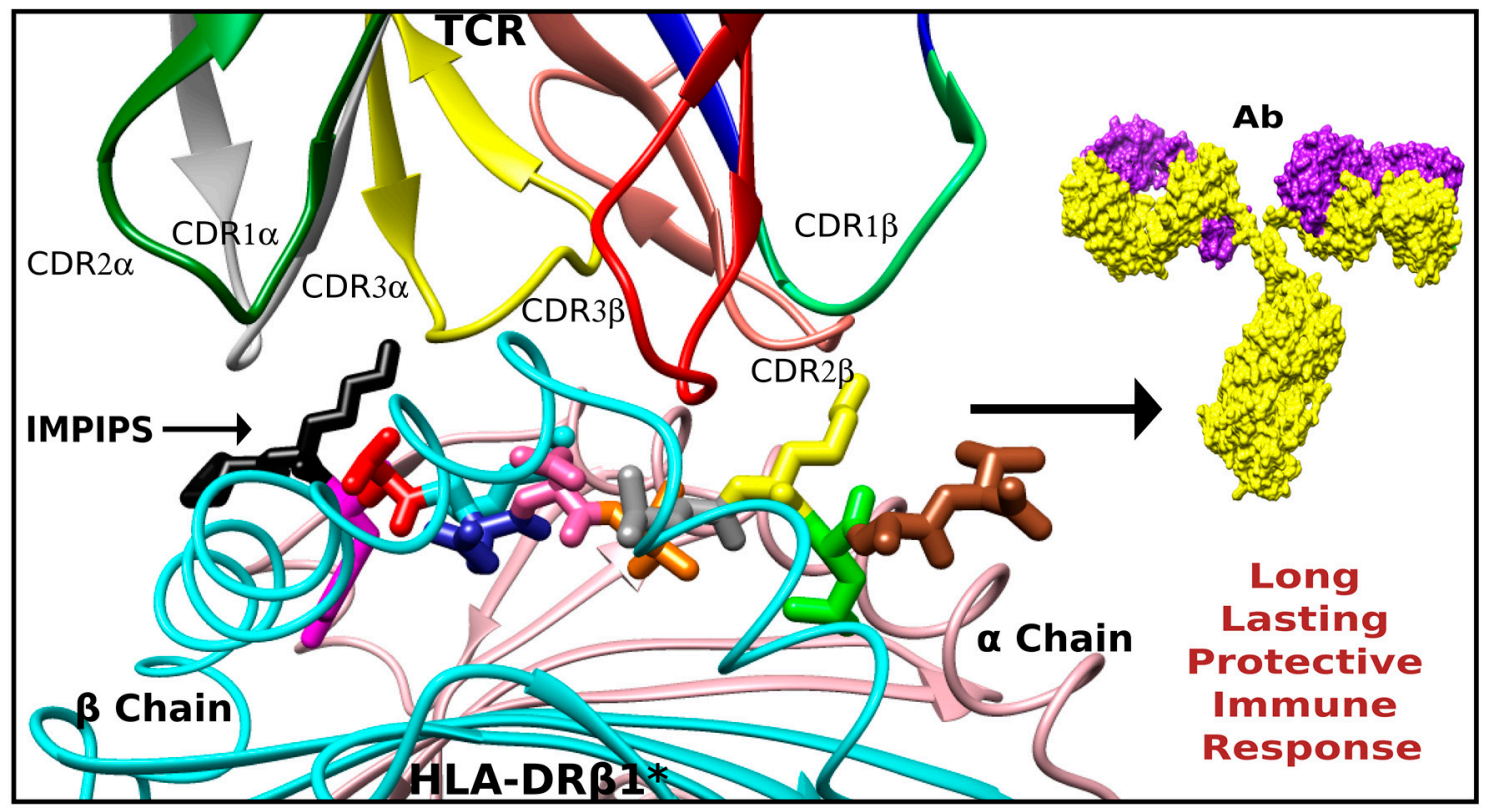

Figure 7. The physical and chemical features which must be taken into account for a peptide-based vaccine candidate design. A perfect fit of the tertiary complex formed by the MHC class II (bottom, ribbon representation), the IMPIPS (middle, stick representation colored as in the Figure 3) and the TCR (displaying the complementary determinant regions loops on each chain in ribbon representation) is the only way to induce a long-lasting and protective immune response.

We would suggest that using synthetic peptides and following the aforementioned rules enables the feasibility of vaccines based on synthetic peptides as subunits to be introduced against infectious diseases, as well as microbe-associated or induced-cancers, in a relatively short time (Figure 7).

Acknowledgments: We would like to thank Jason Garry for reviewing this manuscript and making appropriate corrections regarding the use of English.

Author Contributions: M.E.P. and H.C. conceived and reviewed the manuscript, H.C., C.R., Y.V. and M.V. wrote the manuscript, A.B. and C.R. designed the artwork.

Conflicts of Interest: The authors declare no conflict of interest.

\section{References}

1. Bull, P.C.; Marsh, K. The role of antibodies to Plasmodium falciparum-infected-erythrocyte surface antigens in naturally acquired immunity to malaria. Trends Microbiol. 2002, 10, 55-58. [CrossRef]

2. Bouharoun-Tayoun, H.; Attanath, P.; Sabchareon, A.; Chongsuphajaisiddhi, T.; Druilhe, P. Antibodies that protect humans against Plasmodium falciparum blood stages do not on their own inhibit parasite growth and invasion in vitro, but act in cooperation with monocytes. J. Exp. Med. 1990, 172, 1633-1641. [CrossRef] [PubMed]

3. McGregor, I.A. Studies in the Acquisition of Immunity of Plasmodium Falciparum Infections in Africa. Trans. $R$. Soc. Trop. Med. Hyg. 1964, 58, 80-92. [CrossRef] 
4. Miyahira, Y.; Garcia-Sastre, A.; Rodriguez, D.; Rodriguez, J.R.; Murata, K.; Tsuji, M.; Palese, P.; Esteban, M.; Zavala, F.; Nussenzweig, R.S. Recombinant viruses expressing a human malaria antigen can elicit potentially protective immune CD8+ responses in mice. Proc. Natl. Acad. Sci. USA 1998, 95, 3954-3959. [CrossRef] [PubMed]

5. Rodrigues, E.G.; Zavala, F.; Nussenzweig, R.S.; Wilson, J.M.; Tsuji, M. Efficient induction of protective anti-malaria immunity by recombinant adenovirus. Vaccine 1998, 16, 1812-1817. [CrossRef]

6. Nussenzweig, R.; Vanderberg, J.; Most, H. Protective immunity produced by the injection of x-irradiated sporozoites of Plasmodium berghei. IV. Dose response, specificity and humoral immunity. Mil. Med. 1969, 134, 1176-1182. [PubMed]

7. Weiss, W.R.; Sedegah, M.; Beaudoin, R.L.; Miller, L.H.; Good, M.F. CD8+ T cells (cytotoxic/suppressors) are required for protection in mice immunized with malaria sporozoites. Proc. Natl. Acad. Sci. USA 1988, 85, 573-576. [CrossRef] [PubMed]

8. Gwadz, R.W.; Carter, R.; Green, I. Gamete vaccines and transmission-blocking immunity in malaria. Bull. World Health Organ. 1979, 57 (Suppl. 1), 175-180. [PubMed]

9. Hoffman, S.L.; Goh, L.M.; Luke, T.C.; Schneider, I.; Le, T.P.; Doolan, D.L.; Sacci, J.; de la Vega, P.; Dowler, M.; Paul, C.; et al. Protection of humans against malaria by immunization with radiation-attenuated Plasmodium falciparum sporozoites. J. Infect. Dis. 2002, 185, 1155-1164. [CrossRef] [PubMed]

10. Ishizuka, A.S.; Lyke, K.E.; DeZure, A.; Berry, A.A.; Richie, T.L.; Mendoza, F.H.; Enama, M.E.; Gordon, I.J.; Chang, L.J.; Sarwar, U.N.; et al. Protection against malaria at 1 year and immune correlates following PfSPZ vaccination. Nat. Med. 2016, 22, 614-623. [CrossRef] [PubMed]

11. Patarroyo, M.E.; Amador, R.; Clavijo, P.; Moreno, A.; Guzman, F.; Romero, P.; Tascon, R.; Franco, A.; Murillo, L.A.; Ponton, G.; et al. A synthetic vaccine protects humans against challenge with asexual blood stages of Plasmodium falciparum malaria. Nature 1988, 332, 158-161. [CrossRef] [PubMed]

12. Noya, O.; Gabaldon Berti, Y.; Alarcon de Noya, B.; Borges, R.; Zerpa, N.; Urbaez, J.D.; Madonna, A.; Garrido, E.; Jimenez, M.A.; Borges, R.E.; et al. A population-based clinical trial with the SPf66 synthetic Plasmodium falciparum malaria vaccine in Venezuela. J. Infect. Dis. 1994, 170, 396-402. [CrossRef] [PubMed]

13. Egan, A.F.; Blackman, M.J.; Kaslow, D.C. Vaccine efficacy of recombinant Plasmodium falciparum merozoite surface protein 1 in malaria-naive, -exposed, and/or-rechallenged Aotus vociferans monkeys. Infect. Immun. 2000, 68, 1418-1427. [CrossRef] [PubMed]

14. Douglas, A.D.; Baldeviano, G.C.; Lucas, C.M.; Lugo-Roman, L.A.; Crosnier, C.; Bartholdson, S.J.; Diouf, A.; Miura, K.; Lambert, L.E.; Ventocilla, J.A.; et al. A PfRH5-based vaccine is efficacious against heterologous strain blood-stage Plasmodium falciparum infection in Aotus monkeys. Cell Host Microbe 2015, 17, 130-139. [CrossRef] [PubMed]

15. Collins, W.E.; Anders, R.F.; Pappaioanou, M.; Campbell, G.H.; Brown, G.V.; Kemp, D.J.; Coppel, R.L.; Skinner, J.C.; Andrysiak, P.M.; Favaloro, J.M.; et al. Immunization of Aotus monkeys with recombinant proteins of an erythrocyte surface antigen of Plasmodium falciparum. Nature 1986, 323, 259-262. [CrossRef] [PubMed]

16. WHO. World malaria report. In WHO Global Malaria Programme 2016; World Health Organization: Geneva, Switzerland, 2016.

17. Anderer, F.A. Preparation and properties of an artificial antigen immunologically related to tobacco mosaic virus. Biochim. Biophys. Acta 1963, 71, 246-248. [CrossRef]

18. Merrifield, R.B. Solid Phase Peptide Synthesis. I. The synthesis of a Tetrapeptide. J. Am. Chem. Soc. 1963, 85, 2149-2154. [CrossRef]

19. Collier, J.H.; Segura, T. Evolving the use of peptides as components of biomaterials. Biomaterials 2011, 32, 4198-4204. [CrossRef] [PubMed]

20. Hartgerink, J.D.; Beniash, E.; Stupp, S.I. Self-assembly and mineralization of peptide-amphiphile nanofibers. Science 2001, 294, 1684-1688. [CrossRef] [PubMed]

21. Imondi, A.R.; Stradley, R.P.; Wolgemuth, R. Synthetic peptides in the diagnosis of exocrine pancreatic insufficiency in animals. Gut 1972, 13, 726-731. [CrossRef] [PubMed]

22. Fargeas, C.; Hommel, M.; Maingon, R.; Dourado, C.; Monsigny, M.; Mayer, R. Synthetic peptide-based enzyme-linked immunosorbent assay for serodiagnosis of visceral leishmaniasis. J. Clin. Microbiol. 1996, 34, 241-248. [PubMed] 
23. Volkmer, R.; Kretzschmar, I.; Tapia, V. Mapping receptor-ligand interactions with synthetic peptide arrays: Exploring the structure and function of membrane receptors. Eur. J. Cell Biol. 2012, 91, 349-356. [CrossRef] [PubMed]

24. Garcia, J.E.; Puentes, A.; Patarroyo, M.E. Developmental biology of sporozoite-host interactions in Plasmodium falciparum malaria: Implications for vaccine design. Clin. Microbiol. Rev. 2006, 19, 686-707. [CrossRef] [PubMed]

25. Rodriguez, L.E.; Urquiza, M.; Ocampo, M.; Suarez, J.; Curtidor, H.; Guzman, F.; Vargas, L.E.; Trivinos, M.; Rosas, M.; Patarroyo, M.E. Plasmodium falciparum EBA-175 kDa protein peptides which bind to human red blood cells. Parasitology 2000, 120 Pt 3, 225-235. [CrossRef] [PubMed]

26. Diaz, D.P.; Ocampo, M.; Varela, Y.; Curtidor, H.; Patarroyo, M.A.; Patarroyo, M.E. Identifying and characterising $\mathrm{PPE}_{7}\left(\mathrm{Rvo}_{354 \mathrm{c}}\right)$ high activity binding peptides and their role in inhibiting cell invasion. Mol. Cell. Biochem. 2017, 430, 149-160. [CrossRef] [PubMed]

27. Holmes, T.C. Novel peptide-based biomaterial scaffolds for tissue engineering. Trends Biotechnol. 2002, 20, 16-21. [CrossRef]

28. Boman, H.G.; Wade, D.; Boman, I.A.; Wahlin, B.; Merrifield, R.B. Antibacterial and antimalarial properties of peptides that are cecropin-melittin hybrids. FEBS Lett. 1989, 259, 103-106. [CrossRef]

29. Ge, Y.; MacDonald, D.L.; Holroyd, K.J.; Thornsberry, C.; Wexler, H.; Zasloff, M. In vitro antibacterial properties of pexiganan, an analog of magainin. Antimicrob. Agents Chemother. 1999, 43, 782-788. [PubMed]

30. Mather, R.; Karenchak, L.M.; Romanowski, E.G.; Kowalski, R.P. Fourth generation fluoroquinolones: New weapons in the arsenal of ophthalmic antibiotics. Am. J. Ophthalmol. 2002, 133, 463-466. [CrossRef]

31. Ma, Y.; Ai, G.; Zhang, C.; Zhao, M.; Dong, X.; Han, Z.; Wang, Z.; Zhang, M.; Liu, Y.; Gao, W.; et al. Novel Linear Peptides with High Affinity to $\alpha v \beta 3$ Integrin for Precise Tumor Identification. Theranostics 2017, 7, 1511-1523. [CrossRef] [PubMed]

32. Koliakos, G.; Trontzos, C.; Kouzi-Koliakos, K.; Kanellaki, M.; Grammaticos, P. Lung carcinoma imaging using a synthetic laminin derivative radioiodinated peptide YIGSR. J. Nucl. Med. Off. Publ. Soc. Nucl. Med. 1997, 38, 1940-1944.

33. Lee, T.Y.; Wu, H.C.; Tseng, Y.L.; Lin, C.T. A novel peptide specifically binding to nasopharyngeal carcinoma for targeted drug delivery. Cancer Res. 2004, 64, 8002-8008. [CrossRef] [PubMed]

34. Garanger, E.; Boturyn, D.; Jin, Z.; Dumy, P.; Favrot, M.C.; Coll, J.L. New multifunctional molecular conjugate vector for targeting, imaging, and therapy of tumors. Mol. Ther. J. Am. Soc. Gene Ther. 2005, 12, 1168-1175. [CrossRef] [PubMed]

35. Townsend, A.R.; Gotch, F.M.; Davey, J. Cytotoxic T cells recognize fragments of the influenza nucleoprotein. Cell 1985, 42, 457-467. [CrossRef]

36. Shinnick, T.M.; Sutcliffe, J.G.; Green, N.; Lerner, R.A. Synthetic peptide immunogens as vaccines. Annu. Rev. Microbiol. 1983, 37, 425-446. [CrossRef] [PubMed]

37. McDevitt, H.O.; Sela, M. Genetic control of the antibody response. II. Further analysis of the specificity of determinant-specific control, and genetic analysis of the response to $(\mathrm{H}, \mathrm{G})-\mathrm{A}-\mathrm{L}$ in CBA and C57 mice. J. Exp. Med. 1967, 126, 969-978. [CrossRef] [PubMed]

38. Zavala, F.; Tam, J.P.; Barr, P.J.; Romero, P.J.; Ley, V.; Nussenzweig, R.S.; Nussenzweig, V. Synthetic peptide vaccine confers protection against murine malaria. J. Exp. Med. 1987, 166, 1591-1596. [CrossRef] [PubMed]

39. Patarroyo, M.E.; Romero, P.; Torres, M.L.; Clavijo, P.; Moreno, A.; Martinez, A.; Rodriguez, R.; Guzman, F.; Cabezas, E. Induction of protective immunity against experimental infection with malaria using synthetic peptides. Nature 1987, 328, 629-632. [CrossRef] [PubMed]

40. Arnon, R. Chemically defined antiviral vaccines. Annu. Rev. Microbiol. 1980, 34, 593-618. [CrossRef] [PubMed]

41. Li, W.; Joshi, M.D.; Singhania, S.; Ramsey, K.H.; Murthy, A.K. Peptide Vaccine: Progress and Challenges. Vaccines 2014, 2, 515-536. [CrossRef] [PubMed]

42. Campbell, G.H.; Brandling-Bennett, A.D.; Roberts, J.M.; Collins, F.H.; Kaseje, D.C.; Barber, A.M.; Turner, A. Detection of antibodies in human sera to the repeating epitope of the circumsporozoite protein of Plasmodium falciparum using the synthetic peptide (NANP)3 in an enzyme-linked immunosorbent assay (ELISA). Am. J. Trop. Med. Hyg. 1987, 37, 17-21. [CrossRef] [PubMed] 
43. Zavala, F.; Tam, J.P.; Hollingdale, M.R.; Cochrane, A.H.; Quakyi, I.; Nussenzweig, R.S.; Nussenzweig, V. Rationale for development of a synthetic vaccine against Plasmodium falciparum malaria. Science 1985, 228, 1436-1440. [CrossRef] [PubMed]

44. Rodriguez, R.; Moreno, A.; Guzman, F.; Calvo, M.; Patarroyo, M.E. Studies in owl monkeys leading to the development of a synthetic vaccine against the asexual blood stages of Plasmodium falciparum. Am. J. Trop. Med. Hyg. 1990, 43, 339-354. [CrossRef] [PubMed]

45. Audibert, F.; Jolivet, M.; Chedid, L.; Arnon, R.; Sela, M. Successful immunization with a totally synthetic diphtheria vaccine. Proc. Natl. Acad. Sci. USA 1982, 79, 5042-5046. [CrossRef] [PubMed]

46. Bittle, J.L.; Houghten, R.A.; Alexander, H.; Shinnick, T.M.; Sutcliffe, J.G.; Lerner, R.A.; Rowlands, D.J.; Brown, F. Protection against foot-and-mouth disease by immunization with a chemically synthesized peptide predicted from the viral nucleotide sequence. Nature 1982, 298, 30-33. [CrossRef] [PubMed]

47. DiMarchi, R.; Brooke, G.; Gale, C.; Cracknell, V.; Doel, T.; Mowat, N. Protection of cattle against foot-and-mouth disease by a synthetic peptide. Science 1986, 232, 639-641. [CrossRef] [PubMed]

48. Streckert, H.J.; Brussow, H.; Werchau, H. A synthetic peptide corresponding to the cleavage region of VP3 from rotavirus SA11 induces neutralizing antibodies. J. Virol. 1988, 62, 4265-4269. [PubMed]

49. Chanh, T.C.; Dreesman, G.R.; Kanda, P.; Linette, G.P.; Sparrow, J.T.; Ho, D.D.; Kennedy, R.C. Induction of anti-HIV neutralizing antibodies by synthetic peptides. EMBO J. 1986, 5, 3065-3071. [PubMed]

50. Amador, R.; Moreno, A.; Murillo, L.A.; Sierra, O.; Saavedra, D.; Rojas, M.; Mora, A.L.; Rocha, C.L.; Alvarado, F.; Falla, J.C.; et al. Safety and immunogenicity of the synthetic malaria vaccine SPf66 in a large field trial. J. Infect. Dis. 1992, 166, 139-144. [CrossRef] [PubMed]

51. Amador, R.; Moreno, A.; Valero, V.; Murillo, L.; Mora, A.L.; Rojas, M.; Rocha, C.; Salcedo, M.; Guzman, F.; Espejo, F.; et al. The first field trials of the chemically synthesized malaria vaccine SPf66: Safety, immunogenicity and protectivity. Vaccine 1992, 10, 179-184. [CrossRef]

52. Patarroyo, G.; Franco, L.; Amador, R.; Murillo, L.A.; Rocha, C.L.; Rojas, M.; Patarroyo, M.E. Study of the safety and immunogenicity of the synthetic malaria SPf66 vaccine in children aged 1-14 years. Vaccine 1992, 10, 175-178. [CrossRef]

53. Alonso, P.L.; Smith, T.; Schellenberg, J.R.; Masanja, H.; Mwankusye, S.; Urassa, H.; Bastos de Azevedo, I.; Chongela, J.; Kobero, S.; Menendez, C.; et al. Randomised trial of efficacy of SPf66 vaccine against Plasmodium falciparum malaria in children in southern Tanzania. Lancet 1994, 344, 1175-1181. [CrossRef]

54. Sempertegui, F.; Estrella, B.; Moscoso, J.; Piedrahita, L.; Hernandez, D.; Gaybor, J.; Naranjo, P.; Mancero, O.; Arias, S.; Bernal, R.; et al. Safety, immunogenicity and protective effect of the SPf66 malaria synthetic vaccine against Plasmodium falciparum infection in a randomized double-blind placebo-controlled field trial in an endemic area of Ecuador. Vaccine 1994, 12, 337-342. [CrossRef]

55. Valero, M.V.; Amador, R.; A ponte, J.J.; Narvaez, A.; Galindo, C.; Silva, Y.; Rosas, J.; Guzman, F.; Patarroyo, M.E. Evaluation of SPf66 malaria vaccine during a 22-month follow-up field trial in the Pacific coast of Colombia. Vaccine 1996, 14, 1466-1470. [CrossRef]

56. Langeveld, J.P.; Casal, J.I.; Osterhaus, A.D.; Cortes, E.; de Swart, R.; Vela, C.; Dalsgaard, K.; Puijk, W.C.; Schaaper, W.M.; Meloen, R.H. First peptide vaccine providing protection against viral infection in the target animal: studies of canine parvovirus in dogs. J. Virol. 1994, 68, 4506-4513. [PubMed]

57. Snewin, V.A.; Premawansa, S.; Kapilananda, G.M.; Ratnayaka, L.; Udagama, P.V.; Mattei, D.M.; Khouri, E.; Del Giudice, G.; Peiris, J.S.; Mendis, K.N.; et al. Transmission blocking immunity in Plasmodium vivax malaria: antibodies raised against a peptide block parasite development in the mosquito vector. J. Exp. Med. 1995, 181, 357-362. [CrossRef] [PubMed]

58. Oscherwitz, J.; Yu, F.; Cease, K.B. A synthetic peptide vaccine directed against the 2ss2-2ss3 loop of domain 2 of protective antigen protects rabbits from inhalation anthrax. J. Immunol. 2010, 185, 3661-3668. [CrossRef] [PubMed]

59. Stanekova, Z.; Kiraly, J.; Stropkovska, A.; Mikuskova, T.; Mucha, V.; Kostolansky, F.; Vareckova, E. Heterosubtypic protective immunity against influenza A virus induced by fusion peptide of the hemagglutinin in comparison to ectodomain of M2 protein. Acta Virol. 2011, 55, 61-67. [CrossRef] [PubMed]

60. Monso, M.; Tarradas, J.; de la Torre, B.G.; Sobrino, F.; Ganges, L.; Andreu, D. Peptide vaccine candidates against classical swine fever virus: $\mathrm{T}$ cell and neutralizing antibody responses of dendrimers displaying E2 and NS2-3 epitopes. J. Pept. Sci. 2011, 17, 24-31. [CrossRef] [PubMed] 
61. Solares, A.M.; Baladron, I.; Ramos, T.; Valenzuela, C.; Borbon, Z.; Fanjull, S.; Gonzalez, L.; Castillo, D.; Esmir, J.; Granadillo, M.; et al. Safety and Immunogenicity of a Human Papillomavirus Peptide Vaccine (CIGB-228) in Women with High-Grade Cervical Intraepithelial Neoplasia: First-in-Human, Proof-of-Concept Trial. ISRN Obstet. Gynecol. 2011, 2011, 292951-292959. [CrossRef] [PubMed]

62. Patarroyo, M.E.; Bermudez, A.; Alba, M.P.; Vanegas, M.; Moreno-Vranich, A.; Poloche, L.A.; Patarroyo, M.A. IMPIPS: The Immune Protection-Inducing Protein Structure Concept in the Search for Steric-Electron and Topochemical Principles for Complete Fully-Protective Chemically Synthesised Vaccine Development. PLoS ONE 2015, 10, e0123249. [CrossRef] [PubMed]

63. Patarroyo, M.E.; Patarroyo, M.A.; Pabon, L.; Curtidor, H.; Poloche, L.A. Immune protection-inducing protein structures (IMPIPS) against malaria: The weapons needed for beating Odysseus. Vaccine 2015, 33, 7525-7537. [CrossRef] [PubMed]

64. Acosta, C.J.; Galindo, C.M.; Schellenberg, D.; Aponte, J.J.; Kahigwa, E.; Urassa, H.; Schellenberg, J.R.; Masanja, H.; Hayes, R.; Kitua, A.Y.; et al. Evaluation of the SPf66 vaccine for malaria control when delivered through the EPI scheme in Tanzania. Trop. Med. Int. Health 1999, 4, 368-376. [CrossRef] [PubMed]

65. D'Alessandro, U.; Leach, A.; Drakeley, C.J.; Bennett, S.; Olaleye, B.O.; Fegan, G.W.; Jawara, M.; Langerock, P.; George, M.O.; Targett, G.A.; et al. Efficacy trial of malaria vaccine SPf66 in Gambian infants. Lancet 1995, 346, 462-467. [CrossRef]

66. Graves, P.; Gelband, H. Vaccines for preventing malaria (SPf66). Cochrane Database Syst. Rev. 2006, 2, 1-30.

67. Bozdech, Z.; Llinas, M.; Pulliam, B.L.; Wong, E.D.; Zhu, J.; DeRisi, J.L. The transcriptome of the intraerythrocytic developmental cycle of Plasmodium falciparum. PLoS Biol. 2003, 1, E5. [CrossRef] [PubMed]

68. Bozdech, Z.; Zhu, J.; Joachimiak, M.P.; Cohen, F.E.; Pulliam, B.; DeRisi, J.L. Expression profiling of the schizont and trophozoite stages of Plasmodium falciparum with a long-oligonucleotide microarray. Genome Biol. 2003, 4, R9. [CrossRef] [PubMed]

69. Kappe, S.H.; Gardner, M.J.; Brown, S.M.; Ross, J.; Matuschewski, K.; Ribeiro, J.M.; Adams, J.H.; Quackenbush, J.; Cho, J.; Carucci, D.J.; et al. Exploring the transcriptome of the malaria sporozoite stage. Proc. Natl. Acad. Sci. USA 2001, 98, 9895-9900. [CrossRef] [PubMed]

70. Amino, R.; Thiberge, S.; Martin, B.; Celli, S.; Shorte, S.; Frischknecht, F.; Menard, R. Quantitative imaging of Plasmodium transmission from mosquito to mammal. Nat. Med. 2006, 12, 220-224. [CrossRef] [PubMed]

71. Ejigiri, I.; Sinnis, P. Plasmodium sporozoite-host interactions from the dermis to the hepatocyte. Curr. Opin. Microbiol. 2009, 12, 401-407. [CrossRef] [PubMed]

72. Bannister, L.; Mitchell, G. The ins, outs and roundabouts of malaria. Trends Parasitol. 2003, 19, $209-213$. [CrossRef]

73. Sinden, R.E. Plasmodium differentiation in the mosquito. Parassitologia 1999, 41, 139-148. [PubMed]

74. Pereira da Silva, L. Genetic aspects of malaria parasite infection and the host immune response in relation to parasite evasion. Annal. Parasitol. Hum. Comp. 1990, 65 (Suppl. 1), 15-17. [CrossRef] [PubMed]

75. Casares, S.; Richie, T.L. Immune evasion by malaria parasites: A challenge for vaccine development. Curr. Opin. Immunol. 2009, 21, 321-330. [CrossRef] [PubMed]

76. Hisaeda, H.; Yasutomo, K.; Himeno, K. Malaria: Immune evasion by parasites. Int. J. Biochem. Cell Biol. 2005, 37, 700-706. [CrossRef] [PubMed]

77. Patarroyo, M.E.; Bermudez, A.; Patarroyo, M.A. Structural and immunological principles leading to chemically synthesized, multiantigenic, multistage, minimal subunit-based vaccine development. Chem. Rev. 2011, 111, 3459-3507. [CrossRef] [PubMed]

78. Brodsky, F.M.; Lem, L.; Solache, A.; Bennett, E.M. Human pathogen subversion of antigen presentation. Immunol. Rev. 1999, 168, 199-215. [CrossRef] [PubMed]

79. Patarroyo, M.E.; Aza-Conde, J.; Moreno-Vranich, A.; Pabon, L.; Varela, Y.; Patarroyo, M.A. Far from the Madding Crowd: The Molecular Basis for Immunological Escape of Plasmodium falciparum. Curr. Issues Mol. Biol. 2017, 22, 65-78. [CrossRef] [PubMed]

80. Daubenberger, C.A.; Nickel, B.; Ciatto, C.; Grutter, M.G.; Poltl-Frank, F.; Rossi, L.; Siegler, U.; Robinson, J.; Kashala, O.; Patarroyo, M.E.; et al. Amino acid dimorphism and parasite immune evasion: Cellular immune responses to a promiscuous epitope of Plasmodium falciparum merozoite surface protein 1 displaying dimorphic amino acid polymorphism are highly constrained. Eur. J. Immunol. 2002, 32, 3667-3677. [CrossRef]

81. Schofield, L. The circumsporozoite protein of Plasmodium: A mechanism of immune evasion by the malaria parasite? Bull. World Health Organ. 1990, 68, 66-73. [PubMed] 
82. Kemp, D.J.; Cowman, A.F.; Walliker, D. Genetic diversity in Plasmodium falciparum. Adv. Parasitol. 1990, 29, 75-149. [PubMed]

83. Valero, M.V.; Amador, L.R.; Galindo, C.; Figueroa, J.; Bello, M.S.; Murillo, L.A.; Mora, A.L.; Patarroyo, G.; Rocha, C.L.; Rojas, M.; et al. Vaccination with SPf66, a chemically synthesised vaccine, against Plasmodium falciparum malaria in Colombia. Lancet 1993, 341, 705-710. [CrossRef]

84. Siddiqui, W.A. An effective immunization of experimental monkeys against a human malaria parasite, Plasmodium falciparum. Science 1977, 197, 388-389. [CrossRef] [PubMed]

85. Playfair, J.H.; De Souza, J.B.; Cottrell, B.J. Protection of mice against malaria by a killed vaccine: Differences in effectiveness against P. yoelii and P. berghei. Immunology 1977, 33, 507-515. [PubMed]

86. Nussenzweig, R.S.; Vanderberg, J.; Most, H.; Orton, C. Protective immunity produced by the injection of X-irradiated sporozoites of plasmodium berghei. Nature 1967, 216, 160-162. [CrossRef] [PubMed]

87. Nussenzweig, R.S.; Vanderberg, J.; Spitalny, G.L.; Rivera, C.I.; Orton, C.; Most, H. Sporozoite-induced immunity in mammalian malaria. A review. Am. J. Trop. Med. Hyg. 1972, 21, 722-728. [CrossRef] [PubMed]

88. Russell, P.F.; Mohan, B.N. The Immunization of Fowls against Mosquito-Borne Plasmodium Gallinaceum by Injections of Serum and of Inactivated Homologous Sporozoites. J. Exp. Med. 1942, 76, 477-495. [CrossRef] [PubMed]

89. Perrin, L.H.; Dayal, R.; Rieder, H. Characterization of antigens from erythrocytic stages of Plasmodium falciparum reacting with human immune sera. Trans. R. Soc. Trop. Med. Hyg. 1981, 75, 163-165. [CrossRef]

90. Perrin, L.H.; Ramirez, E.; Lambert, P.H.; Miescher, P.A. Inhibition of P. falciparum growth in human erythrocytes by monoclonal antibodies. Nature 1981, 289, 301-303. [CrossRef] [PubMed]

91. Kan, S.C.; Yamaga, K.M.; Kramer, K.J.; Case, S.E.; Siddiqui, W.A. Plasmodium falciparum: Protein antigens identified by analysis of serum samples from vaccinated Aotus monkeys. Infect. Immun. 1984, 43, $276-282$. [PubMed]

92. Villard, V.; Agak, G.W.; Frank, G.; Jafarshad, A.; Servis, C.; Nebie, I.; Sirima, S.B.; Felger, I.; Arevalo-Herrera, M.; Herrera, S.; et al. Rapid identification of malaria vaccine candidates based on $\alpha$-helical coiled coil protein motif. PLoS ONE 2007, 2, e645. [CrossRef] [PubMed]

93. Perrin, L.H.; Simitsek, P.; Fasani-Ghersa, P. Asexual blood stage vaccines: From merozoites to peptides. Trans. R. Soc. Trop. Med. Hyg. 1989, 83, 53-56. [CrossRef]

94. Perlmann, H.; Berzins, K.; Wahlgren, M.; Carlsson, J.; Bjorkman, A.; Patarroyo, M.E.; Perlmann, P. Antibodies in malarial sera to parasite antigens in the membrane of erythrocytes infected with early asexual stages of Plasmodium falciparum. J. Exp. Med. 1984, 159, 1686-1704. [CrossRef] [PubMed]

95. Wahlin, B.; Wahlgren, M.; Perlmann, H.; Berzins, K.; Bjorkman, A.; Patarroyo, M.E.; Perlmann, P. Human antibodies to a Mr 155,000 Plasmodium falciparum antigen efficiently inhibit merozoite invasion. Proc. Natl. Acad. Sci. USA 1984, 81, 7912-7916. [CrossRef] [PubMed]

96. Carucci, D.J.; Gardner, M.J.; Tettelin, H.; Cummings, L.M.; Smith, H.O.; Adams, M.D.; Venter, J.C.; Hoffman, S.L. Sequencing the genome of Plasmodium falciparum. Curr. Opin. Infect. Dis. 1998, 11, 531-534. [CrossRef] [PubMed]

97. Gardner, M.J.; Tettelin, H.; Carucci, D.J.; Cummings, L.M.; Aravind, L.; Koonin, E.V.; Shallom, S.; Mason, T.; Yu, K.; Fujii, C.; et al. Chromosome 2 sequence of the human malaria parasite Plasmodium falciparum. Science 1998, 282, 1126-1132. [CrossRef] [PubMed]

98. Florens, L.; Washburn, M.P.; Raine, J.D.; Anthony, R.M.; Grainger, M.; Haynes, J.D.; Moch, J.K.; Muster, N.; Sacci, J.B.; Tabb, D.L.; et al. A proteomic view of the Plasmodium falciparum life cycle. Nature 2002, 419, 520-526. [CrossRef] [PubMed]

99. Singh, S.P.; Khan, F.; Mishra, B.N. Computational characterization of Plasmodium falciparum proteomic data for screening of potential vaccine candidates. Hum. Immunol. 2010, 71, 136-143. [CrossRef] [PubMed]

100. Tuju, J.; Kamuyu, G.; Murungi, L.M.; Osier, F.H.A. Vaccine candidate discovery for the next generation of malaria vaccines. Immunology 2017, 152, 195-206. [CrossRef] [PubMed]

101. Patarroyo, M.E.; Vinasco, J.; Amador, R.; Espejo, F.; Silva, Y.; Moreno, A.; Rojas, M.; Mora, A.L.; Salcedo, M.; Valero, V.; et al. Genetic control of the immune response to a synthetic vaccine against Plasmodium falciparum. Parasite Immunol. 1991, 13, 509-516. [CrossRef] [PubMed]

102. Salcedo, M.; Barreto, L.; Rojas, M.; Moya, R.; Cote, J.; Patarroyo, M.E. Studies on the humoral immune response to a synthetic vaccine against Plasmodium falciparum malaria. Clin. Exp. Immunol. 1991, 84, 122-128. [CrossRef] [PubMed] 
103. Van Schravendijk, M.R.; Rock, E.P.; Marsh, K.; Ito, Y.; Aikawa, M.; Neequaye, J.; Ofori-Adjei, D.; Rodriguez, R.; Patarroyo, M.E.; Howard, R.J. Characterization and localization of Plasmodium falciparum surface antigens on infected erythrocytes from west African patients. Blood 1991, 78, 226-236. [PubMed]

104. Wahlgren, M.; Bejarano, M.T.; Troye-Blomberg, M.; Perlmann, P.; Riley, E.; Greenwood, B.M.; Patarroyo, M.E.; Gonzales, C.I.; Martinez, A. Epitopes of the Plasmodium falciparum clustered-asparagine-rich protein (CARP) recognized by human T-cells and antibodies. Parasite Immunol. 1991, 13, 681-694. [CrossRef] [PubMed]

105. Calvo, M.; Guzman, F.; Perez, E.; Segura, C.H.; Molano, A.; Patarroyo, M.E. Specific interactions of synthetic peptides derived from $P$. falciparum merozoite proteins with human red blood cells. Pept. Res. 1991, 4, 324-333. [PubMed]

106. Weiland, G.A.; Molinoff, P.B. Quantitative analysis of drug-receptor interactions: I. Determination of kinetic and equilibrium properties. Life Sci. 1981, 29, 313-330. [CrossRef]

107. Urquiza, M.; Rodriguez, L.E.; Suarez, J.E.; Guzman, F.; Ocampo, M.; Curtidor, H.; Segura, C.; Trujillo, E.; Patarroyo, M.E. Identification of Plasmodium falciparum MSP-1 peptides able to bind to human red blood cells. Parasite Immunol. 1996, 18, 515-526. [CrossRef] [PubMed]

108. Curtidor, H.; Patino, L.C.; Arevalo-Pinzon, G.; Patarroyo, M.E.; Patarroyo, M.A. Identification of the Plasmodium falciparum rhoptry neck protein 5 (PfRON5). Gene 2011, 474, 22-28. [CrossRef] [PubMed]

109. Curtidor, H.; Urquiza, M.; Suarez, J.E.; Rodriguez, L.E.; Ocampo, M.; Puentes, A.; Garcia, J.E.; Vera, R.; Lopez, R.; Ramirez, L.E.; et al. Plasmodium falciparum acid basic repeat antigen (ABRA) peptides: Erythrocyte binding and biological activity. Vaccine 2001, 19, 4496-4504. [CrossRef]

110. Curtidor, H.; Vanegas, M.; Alba, M.P.; Patarroyo, M.E. Functional, immunological and three-dimensional analysis of chemically synthesised sporozoite peptides as components of a fully-effective antimalarial vaccine. Curr. Med. Chem. 2011, 18, 4470-4502. [CrossRef] [PubMed]

111. Rodriguez, L.E.; Curtidor, H.; Urquiza, M.; Cifuentes, G.; Reyes, C.; Patarroyo, M.E. Intimate molecular interactions of $P$. falciparum merozoite proteins involved in invasion of red blood cells and their implications for vaccine design. Chem. Rev. 2008, 108, 3656-3705. [CrossRef] [PubMed]

112. Curtidor, H.; Rodriguez, L.E.; Ocampo, M.; Lopez, R.; Garcia, J.E.; Valbuena, J.; Vera, R.; Puentes, A.; Vanegas, M.; Patarroyo, M.E. Specific erythrocyte binding capacity and biological activity of Plasmodium falciparum erythrocyte binding ligand 1 (EBL-1)-derived peptides. Protein Sci. Publ. Protein Soc. 2005, 14, 464-473. [CrossRef] [PubMed]

113. Patarroyo, M.E.; Arevalo-Pinzon, G.; Reyes, C.; Moreno-Vranich, A.; Patarroyo, M.A. Malaria Parasite Survival Depends on Conserved Binding Peptides' Critical Biological Functions. Curr. Issues Mol. Biol. 2016, 18, 57-78. [PubMed]

114. Alba, M.P.; Salazar, L.M.; Puentes, A.; Pinto, M.; Torres, E.; Patarroyo, M.E. 6746 SERA peptide analogues immunogenicity and protective efficacy against malaria is associated with short $\alpha$ helix formation: Malaria protection associated with peptides $\alpha$ helix shortening. Peptides 2003, 24, 999-1006. [CrossRef]

115. Espejo, F.; Cubillos, M.; Salazar, L.M.; Guzman, F.; Urquiza, M.; Ocampo, M.; Silva, Y.; Rodriguez, R.; Lioy, E.; Patarroyo, M.E. Structure, Immunogenicity, and Protectivity Relationship for the 1585 Malarial Peptide and Its Substitution Analogues. Angew. Chem. Int. Ed. Engl. 2001, 40, 4654-4657. [CrossRef]

116. Guzman, F.; Jaramillo, K.; Salazar, L.M.; Torres, A.; Rivera, A.; Patarroyo, M.E. ${ }^{1}$ H-NMR structures of the Plasmodium falciparum 1758 erythrocyte binding peptide analogues and protection against malaria. Life Sci. 2002, 71, 2773-2785. [CrossRef]

117. Purmova, J.; Salazar, L.M.; Espejo, F.; Torres, M.H.; Cubillos, M.; Torres, E.; Lopez, Y.; Rodriguez, R.; Patarroyo, M.E. NMR structure of Plasmodium falciparum malaria peptide correlates with protective immunity. Biochim. Biophys. Acta 2002, 1571, 27-33. [CrossRef]

118. Herrington, D.A.; Clyde, D.F.; Losonsky, G.; Cortesia, M.; Murphy, J.R.; Davis, J.; Baqar, S.; Felix, A.M.; Heimer, E.P.; Gillessen, D.; et al. Safety and immunogenicity in man of a synthetic peptide malaria vaccine against Plasmodium falciparum sporozoites. Nature 1987, 328, 257-259. [CrossRef] [PubMed]

119. Takala, S.L.; Plowe, C.V. Genetic diversity and malaria vaccine design, testing and efficacy: Preventing and overcoming 'vaccine resistant malaria'. Parasite Immunol. 2009, 31, 560-573. [CrossRef] [PubMed]

120. Escalante, A.A.; Lal, A.A.; Ayala, F.J. Genetic polymorphism and natural selection in the malaria parasite Plasmodium falciparum. Genetics 1998, 149, 189-202. [PubMed]

121. Ahouidi, A.D.; Bei, A.K.; Neafsey, D.E.; Sarr, O.; Volkman, S.; Milner, D.; Cox-Singh, J.; Ferreira, M.U.; Ndir, O.; Premji, Z.; et al. Population genetic analysis of large sequence polymorphisms in Plasmodium falciparum blood-stage antigens. Infect. Genet. Evol. 2010, 10, 200-206. [CrossRef] [PubMed] 
122. Patthy, L. Protein Evolution, 2nd ed.; Blackwell Publishing Ltd.: Hoboken, NJ, USA, 1999.

123. Patarroyo, M.E.; Alba, M.P.; Reyes, C.; Rojas-Luna, R.; Patarroyo, M.A. The Malaria Parasite's Achilles' Heel: Functionally-relevant Invasion Structures. Curr. Issues Mol. Biol. 2016, 18, 11-19. [PubMed]

124. Patarroyo, M.E.; Alba, M.P.; Rojas-Luna, R.; Bermudez, A.; Aza-Conde, J. Functionally relevant proteins in Plasmodium falciparum host cell invasion. Immunotherapy 2017, 9, 131-155. [CrossRef] [PubMed]

125. Cifuentes, G.; Bermudez, A.; Rodriguez, R.; Patarroyo, M.A.; Patarroyo, M.E. Shifting the polarity of some critical residues in malarial peptides' binding to host cells is a key factor in breaking conserved antigens' code of silence. Med. Chem. 2008, 4, 278-292. [CrossRef] [PubMed]

126. Espejo, F.; Bermudez, A.; Torres, E.; Urquiza, M.; Rodriguez, R.; Lopez, Y.; Patarroyo, M.E. Shortening and modifying the 1513 MSP-1 peptide's $\alpha$-helical region induces protection against malaria. Biochem. Biophys. Res. Commun. 2004, 315, 418-427. [CrossRef] [PubMed]

127. Brown, J.H.; Jardetzky, T.S.; Gorga, J.C.; Stern, L.J.; Urban, R.G.; Strominger, J.L.; Wiley, D.C. Three-dimensional structure of the human class II histocompatibility antigen HLA-DR1. Nature 1993, 364, 33-39. [CrossRef] [PubMed]

128. Zinkernagel, R.M.; Doherty, P.C. Restriction of in vitro T cell-mediated cytotoxicity in lymphocytic choriomeningitis within a syngeneic or semiallogeneic system. Nature 1974, 248, 701-702. [CrossRef] [PubMed]

129. Zinkernagel, R.M.; Doherty, P.C. The discovery of MHC restriction. Immunol. Today 1997, 18, 14-17. [CrossRef]

130. Rammensee, H.G.; Friede, T.; Stevanoviic, S. MHC ligands and peptide motifs: First listing. Immunogenetics 1995, 41, 178-228. [CrossRef] [PubMed]

131. Diaz, D.; Daubenberger, C.A.; Zalac, T.; Rodriguez, R.; Patarroyo, M.E. Sequence and expression of MHC-DPB1 molecules of the New World monkey Aotus nancymaae, a primate model for Plasmodium falciparum. Immunogenetics 2002, 54, 251-259. [CrossRef] [PubMed]

132. Diaz, O.L.; Daubenberger, C.A.; Rodriguez, R.; Naegeli, M.; Moreno, A.; Patarroyo, M.E.; Pluschke, G. Immunoglobulin kappa light-chain $V, J$, and $C$ gene sequences of the owl monkey Aotus nancymaae. Immunogenetics 2000, 51, 212-218. [CrossRef] [PubMed]

133. Suarez, C.F.; Patarroyo, M.E.; Trujillo, E.; Estupinan, M.; Baquero, J.E.; Parra, C.; Rodriguez, R. Owl monkey MHC-DRB exon 2 reveals high similarity with several HLA-DRB lineages. Immunogenetics 2006, 58, 542-558. [CrossRef] [PubMed]

134. Young, M.D.; Porter, J.A., Jr.; Johnson, C.M. Plasmodium vivax transmitted from man to monkey to man. Science 1966, 153, 1006-1007. [CrossRef] [PubMed]

135. Moncada, C.A.; Guerrero, E.; Cardenas, P.; Suarez, C.F.; Patarroyo, M.E.; Patarroyo, M.A. The T-cell receptor in primates: Identifying and sequencing new owl monkey TRBV gene sub-groups. Immunogenetics 2005, 57, 42-52. [CrossRef] [PubMed]

136. Ye, Z.; Van Dyke, K.; Rossan, R.N. Effective treatment with a tetrandrine/chloroquine combination for chloroquine-resistant falciparum malaria in Aotus monkeys. Malar. J. 2013, 12, 117. [CrossRef] [PubMed]

137. Powles, L.; Xiang, S.D.; Selomulya, C.; Plebanski, M. The Use of Synthetic Carriers in Malaria Vaccine Design. Vaccines 2015, 3, 894-929. [CrossRef] [PubMed]

138. Rosas, J.E.; Hernandez, R.M.; Gascon, A.R.; Igartua, M.; Guzman, F.; Patarroyo, M.E.; Pedraz, J.L. Biodegradable PLGA microspheres as a delivery system for malaria synthetic peptide SPf66. Vaccine 2001, 19, 4445-4451. [CrossRef]

139. Alexander, J.; del Guercio, M.F.; Maewal, A.; Qiao, L.; Fikes, J.; Chesnut, R.W.; Paulson, J.; Bundle, D.R.; DeFrees, S.; Sette, A. Linear PADRE T helper epitope and carbohydrate B cell epitope conjugates induce specific high titer IgG antibody responses. J. Immunol. 2000, 164, 1625-1633. [CrossRef] [PubMed]

140. Siddiqui, W.A.; Taylor, D.W.; Kan, S.C.; Kramer, K.; Richmond-Crum, S.M.; Kotani, S.; Shiba, T.; Kasumoto, S. Immunization of experimental monkeys against Plasmodium falciparum: Use of synthetic adjuvants. Bull. World Health Organ. 1979, 57 (Suppl. 1), 199-203. [PubMed]

141. Good, M.F.; Yanow, S.K. Cryptic epitope for antibodies should not be forgotten in vaccine design. Expert Rev. Vaccines 2016, 15, 675-676. [CrossRef] [PubMed]

142. Mahajan, B.; Berzofsky, J.A.; Boykins, R.A.; Majam, V.; Zheng, H.; Chattopadhyay, R.; de la Vega, P.; Moch, J.K.; Haynes, J.D.; Belyakov, I.M.; et al. Multiple antigen peptide vaccines against Plasmodium falciparum malaria. Infect. Immun. 2010, 78, 4613-4624. [CrossRef] [PubMed]

143. O'Brien, C.; Flower, D.R.; Feighery, C. Peptide length significantly influences in vitro affinity for MHC class II molecules. Immunome Res. 2008, 4, 6. [CrossRef] [PubMed] 
144. Lin, H.H.; Zhang, G.L.; Tongchusak, S.; Reinherz, E.L.; Brusic, V. Evaluation of MHC-II peptide binding prediction servers: Applications for vaccine research. BMC Bioinform. 2008, 9 (Suppl. 12), S22. [CrossRef] [PubMed]

145. Berzofsky, J.A.; Ahlers, J.D.; Belyakov, I.M. Strategies for designing and optimizing new generation vaccines. Nat. Rev. Immunol. 2001, 1, 209-219. [CrossRef] [PubMed]

146. Alba, M.P.; Salazar, L.M.; Vargas, L.E.; Trujillo, M.; Lopez, Y.; Patarroyo, M.E. Modifying RESA protein peptide 6671 to fit into HLA-DR $\beta_{1}{ }^{*}$ pockets induces protection against malaria. Biochem. Biophys. Res. Commun. 2004, 315, 1154-1164. [CrossRef] [PubMed]

147. Cifuentes, G.; Guzman, F.; Alba, M.P.; Salazar, L.M.; Patarroyo, M.E. Analysis of a Plasmodium falciparum EBA-175 peptide with high binding capacity to erythrocytes and their analogues using 1H-NMR. J. Struct. Biol. 2003, 141, 115-121. [CrossRef]

148. Getzoff, E.D.; Tainer, J.A.; Lerner, R.A.; Geysen, H.M. The chemistry and mechanism of antibody binding to protein antigens. Adv. Immunol. 1988, 43, 1-98. [PubMed]

149. Allen, P.M.; Matsueda, G.R.; Adams, S.; Freeman, J.; Roof, R.W.; Lambert, L.; Unanue, E.R. Enhanced immunogenicity of a $\mathrm{T}$ cell immunogenic peptide by modifications of its $\mathrm{N}$ and $\mathrm{C}$ termini. Int. Immunol. 1989, 1, 141-150. [CrossRef] [PubMed]

150. Patarroyo, M.E.; Alba, M.P.; Vargas, L.E.; Silva, Y.; Rosas, J.; Rodriguez, R. Peptides inducing short-lived antibody responses against Plasmodium falciparum malaria have shorter structures and are read in a different MHC II functional register. Biochemistry 2005, 44, 6745-6754. [CrossRef] [PubMed]

151. Patarroyo, M.E.; Patarroyo, M.A. Emerging rules for subunit-based, multiantigenic, multistage chemically synthesized vaccines. Acc. Chem. Res. 2008, 41, 377-386. [CrossRef] [PubMed]

152. Salazar, L.M.; Alba, M.P.; Curtidor, H.; Bermudez, A.; Luis, E.V.; Rivera, Z.J.; Patarroyo, M.E. Changing ABRA protein peptide to fit into the HLA-DR $\beta 1^{*} 0301$ molecule renders it protection-inducing. Biochem. Biophys. Res. Commun. 2004, 322, 119-125. [CrossRef] [PubMed]

153. Salazar, L.M.; Alba, M.P.; Torres, M.H.; Pinto, M.; Cortes, X.; Torres, L.; Patarroyo, M.E. Protection against experimental malaria associated with AMA-1 peptide analogue structures. FEBS Lett. 2002, 527, 95-100. [CrossRef]

154. Patarroyo, M.E.; Bermudez, A.; Moreno-Vranich, A. Towards the development of a fully protective Plasmodium falciparum antimalarial vaccine. Expert Rev. Vaccines 2012, 11, 1057-1070. [CrossRef] [PubMed]

155. Patarroyo, M.E.; Cifuentes, G.; Vargas, L.E.; Rosas, J. Structural modifications enable conserved peptides to fit into MHC molecules thus inducing protection against malaria. Chembiochem Eur. J. Chem. Biol. 2004, 5, 1588-1593. [CrossRef] [PubMed]

156. Patarroyo, M.A.; Bermudez, A.; Lopez, C.; Yepes, G.; Patarroyo, M.E. 3D analysis of the TCR/pMHCII complex formation in monkeys vaccinated with the first peptide inducing sterilizing immunity against human malaria. PLoS ONE 2010, 5, e9771. [CrossRef] [PubMed]

157. Strominger, J.L. Human histocompatibility proteins. Immunol. Rev. 2002, 185, 69-77. [CrossRef] [PubMed]

158. Vandiedonck, C.; Knight, J.C. The human Major Histocompatibility Complex as a paradigm in genomics research. Brief. Funct. Genom. Proteom. 2009, 8, 379-394. [CrossRef] [PubMed]

159. Davis, M.M.; Bjorkman, P.J. T-cell antigen receptor genes and T-cell recognition. Nature 1988, 334, $395-402$. [CrossRef] [PubMed]

160. Horton, R.; Wilming, L.; Rand, V.; Lovering, R.C.; Bruford, E.A.; Khodiyar, V.K.; Lush, M.J.; Povey, S.; Talbot, C.C., Jr.; Wright, M.W.; et al. Gene map of the extended human MHC. Nat. Rev. Genet. 2004, 5, 889-899. [CrossRef] [PubMed]

161. Klein, J.; Sato, A. The HLA system. Second of two parts. N. Engl. J. Med. 2000, 343, 782-786. [CrossRef] [PubMed]

162. Klein, J.; Sato, A. The HLA system. First of two parts. N. Engl. J. Med. 2000, 343, 702-709. [CrossRef] [PubMed]

163. Hewitt, E.W. The MHC class I antigen presentation pathway: Strategies for viral immune evasion. Immunology 2003, 110, 163-169. [CrossRef] [PubMed]

164. Albring, J.; Koopmann, J.O.; Hammerling, G.J.; Momburg, F. Retrotranslocation of MHC class I heavy chain from the endoplasmic reticulum to the cytosol is dependent on ATP supply to the ER lumen. Mol. Immunol. 2004, 40, 733-741. [CrossRef] [PubMed] 
165. Neefjes, J.; Jongsma, M.L.; Paul, P.; Bakke, O. Towards a systems understanding of MHC class I and MHC class II antigen presentation. Nat. Rev. Immunol. 2011, 11, 823-836. [CrossRef] [PubMed]

166. Cole, D.K.; van den Berg, H.A.; Lloyd, A.; Crowther, M.D.; Beck, K.; Ekeruche-Makinde, J.; Miles, J.J.; Bulek, A.M.; Dolton, G.; Schauenburg, A.J.; et al. Structural Mechanism Underpinning Cross-reactivity of a CD8+ T-cell Clone That Recognizes a Peptide Derived from Human Telomerase Reverse Transcriptase. J. Biol. Chem. 2017, 292, 802-813. [CrossRef] [PubMed]

167. Ghosh, P.; Amaya, M.; Mellins, E.; Wiley, D.C. The structure of an intermediate in class II MHC maturation: CLIP bound to HLA-DR3. Nature 1995, 378, 457-462. [CrossRef] [PubMed]

168. Hennecke, J.; Wiley, D.C. Structure of a complex of the human alpha/beta T cell receptor (TCR) HA1.7, influenza hemagglutinin peptide, and major histocompatibility complex class II molecule, HLA-DR4 (DRA*0101 and DRB1*0401): insight into TCR cross-restriction and alloreactivity. J. Exp. Med. 2002, 195, 571-581. [CrossRef] [PubMed]

169. Castellino, F.; Zhong, G.; Germain, R.N. Antigen presentation by MHC class II molecules: Invariant chain function, protein trafficking, and the molecular basis of diverse determinant capture. Hum. Immunol. 1997, 54, 159-169. [CrossRef]

170. Beck, H.P.; Felger, I.; Barker, M.; Bugawan, T.; Genton, B.; Alexander, N.; Jazwinska, E.; Erlich, H.; Alpers, M. Evidence of HLA class II association with antibody response against the malaria vaccine SPF66 in a naturally exposed population. Am. J. Trop. Med. Hyg. 1995, 53, 284-288. [PubMed]

171. Draheim, M.; Wlodarczyk, M.F.; Crozat, K.; Saliou, J.M.; Alayi, T.D.; Tomavo, S.; Hassan, A.; Salvioni, A.; Demarta-Gatsi, C.; Sidney, J.; et al. Profiling MHC II immunopeptidome of blood-stage malaria reveals that cDC1 control the functionality of parasite-specific CD4 T cells. EMBO Mol. Med. 2017, 9, 1605-1621. [CrossRef] [PubMed]

172. Ndungu, F.M.; Sanni, L.; Urban, B.; Stephens, R.; Newbold, C.I.; Marsh, K.; Langhorne, J. CD4 T cells from malaria-nonexposed individuals respond to the CD36-Binding Domain of Plasmodium falciparum erythrocyte membrane protein-1 via an MHC class II-TCR-independent pathway. J. Immunol. 2006, 176, 5504-5512. [CrossRef] [PubMed]

173. Cigel, F.; Batchelder, J.; Burns, J.M., Jr.; Yanez, D.; van der Heyde, H.; Manning, D.D.; Weidanz, W.P. Immunity to blood-stage murine malarial parasites is MHC class II dependent. Immunol. Lett. 2003, 89, 243-249. [CrossRef]

174. Rammensee, H.G. Chemistry of peptides associated with MHC class I and class II molecules. Curr. Opin. Immunol. 1995, 7, 85-96. [CrossRef]

175. Stern, L.J.; Brown, J.H.; Jardetzky, T.S.; Gorga, J.C.; Urban, R.G.; Strominger, J.L.; Wiley, D.C. Crystal structure of the human class II MHC protein HLA-DR1 complexed with an influenza virus peptide. Nature 1994, 368, 215-221. [CrossRef] [PubMed]

176. Patarroyo, M.E.; Moreno-Vranich, A.; Bermudez, A. Phi (Phi) and psi (Psi) angles involved in malarial peptide bonds determine sterile protective immunity. Biochem. Biophys. Res. Commun. 2012, 429, 75-80. [CrossRef] [PubMed]

177. Urquiza, M.; Suarez, J.E.; Cardenas, C.; Lopez, R.; Puentes, A.; Chavez, F.; Calvo, J.C.; Patarroyo, M.E. Plasmodium falciparum AMA-1 erythrocyte binding peptides implicate AMA-1 as erythrocyte binding protein. Vaccine 2000, 19, 508-513. [CrossRef]

178. Bermudez, A.; Calderon, D.; Moreno-Vranich, A.; Almonacid, H.; Patarroyo, M.A.; Poloche, A.; Patarroyo, M.E. Gauche(+) side chain orientation as a key factor in the search for an immunogenic peptide mixture leading to a complete fully protective vaccine. Vaccine 2014, 32, 2117-2126. [CrossRef] [PubMed]

179. Agudelo, W.A.; Galindo, J.F.; Patarroyo, M.E. Electrostatic potential as a tool to understand interactions between malaria vaccine candidate peptides and MHC II molecules. Biochem. Biophys. Res. Commun. 2011, 410, 410-415. [CrossRef] [PubMed]

180. Biro, J.C. Amino acid size, charge, hydropathy indices and matrices for protein structure analysis. Theor. Biol. Med. Model. 2006, 3, 15. [CrossRef] [PubMed]

181. Dagliyan, O.; Proctor, E.A.; D'Auria, K.M.; Ding, F.; Dokholyan, N.V. Structural and dynamic determinants of protein-peptide recognition. Structure 2011, 19, 1837-1845. [CrossRef] [PubMed]

182. Ding, F.; Tsao, D.; Nie, H.; Dokholyan, N.V. Ab initio folding of proteins with all-atom discrete molecular dynamics. Structure 2008, 16, 1010-1018. [CrossRef] [PubMed] 
183. Hughes, T.J.; Popelier, P.L.A. Where does charge reside in amino acids? The effect of side chain protonation state on the atomic charges of Asp, Glu, Lys, His and Arg. Comput. Theor. Chem. 2015, 1053, 298-304. [CrossRef]

184. Yuan, Y.; Mills, M.J.; Popelier, P.L.; Jensen, F. Comprehensive analysis of energy minima of the 20 natural amino acids. J. Phys. Chem. A 2014, 118, 7876-7891. [CrossRef] [PubMed]

185. Boehncke, W.H.; Takeshita, T.; Pendleton, C.D.; Houghten, R.A.; Sadegh-Nasseri, S.; Racioppi, L.; Berzofsky, J.A.; Germain, R.N. The importance of dominant negative effects of amino acid side chain substitution in peptide-MHC molecule interactions and T cell recognition. J. Immunol. 1993, 150, 331-341. [PubMed]

186. Kim, Y.; Sidney, J.; Pinilla, C.; Sette, A.; Peters, B. Derivation of an amino acid similarity matrix for peptide: MHC binding and its application as a Bayesian prior. BMC Bioinform. 2009, 10, 394. [CrossRef] [PubMed]

187. Suarez, C.F.; Pabon, L.; Barrera, A.; Aza-Conde, J.; Patarroyo, M.A.; Patarroyo, M.E. Structural analysis of owl monkey MHC-DR shows that fully-protective malaria vaccine components can be readily used in humans. Biochem. Biophys. Res. Commun. 2017, 491, 1062-1069. [CrossRef] [PubMed]

188. Jardetzky, T.S.; Brown, J.H.; Gorga, J.C.; Stern, L.J.; Urban, R.G.; Chi, Y.I.; Stauffacher, C.; Strominger, J.L.; Wiley, D.C. Three-dimensional structure of a human class II histocompatibility molecule complexed with superantigen. Nature 1994, 368, 711-718. [CrossRef] [PubMed]

189. Espejo, F.; Bermudez, A.; Vanegas, M.; Rivera, Z.; Torres, E.; Salazar, L.M.; Patarroyo, M.E. Elongating modified conserved peptides eliminates their immunogenicity and protective efficacy against $\mathrm{P}$. falciparum malaria. J. Struct. Biol. 2005, 150, 245-258. [CrossRef] [PubMed]

190. Jardetzky, T.S.; Brown, J.H.; Gorga, J.C.; Stern, L.J.; Urban, R.G.; Strominger, J.L.; Wiley, D.C. Crystallographic analysis of endogenous peptides associated with HLA-DR1 suggests a common, polyproline II-like conformation for bound peptides. Proc. Natl. Acad. Sci. USA 1996, 93, 734-738. [CrossRef] [PubMed]

191. Arnott, S.; Dover, S.D. The structure of poly-L-proline II. Acta Crystallogr. Sect. B Struct. Crystallogr. Cryst. Chem. 1968, 24, 599-601. [CrossRef]

192. Stapley, B.J.; Creamer, T.P. A survey of left-handed polyproline II helices. Protein Sci. Publ. Protein Soc. 1999, 8, 587-595. [CrossRef] [PubMed]

193. Sreerama, N.; Woody, R.W. Poly(pro)II helices in globular proteins: Identification and circular dichroic analysis. Biochemistry 1994, 33, 10022-10025. [CrossRef] [PubMed]

194. Adzhubei, A.A.; Sternberg, M.J. Left-handed polyproline II helices commonly occur in globular proteins. J. Mol. Biol. 1993, 229, 472-493. [CrossRef] [PubMed]

195. Rucker, A.L.; Pager, C.T.; Campbell, M.N.; Qualls, J.E.; Creamer, T.P. Host-guest scale of left-handed polyproline II helix formation. Proteins 2003, 53, 68-75. [CrossRef] [PubMed]

196. Drake, A.F.; Siligardi, G.; Gibbons, W.A. Reassessment of the electronic circular dichroism criteria for random coil conformations of poly(L-lysine) and the implications for protein folding and denaturation studies. Biophys. Chem. 1988, 31, 143-146. [CrossRef]

197. Venugopal, M.G.; Ramshaw, J.A.; Braswell, E.; Zhu, D.; Brodsky, B. Electrostatic interactions in collagen-like triple-helical peptides. Biochemistry 1994, 33, 7948-7956. [CrossRef] [PubMed]

198. Rath, A.; Davidson, A.R.; Deber, C.M. The structure of "unstructured" regions in peptides and proteins: Role of the polyproline II helix in protein folding and recognition. Biopolymers 2005, 80, 179-185. [CrossRef] [PubMed]

199. Adzhubei, A.A.; Sternberg, M.J.; Makarov, A.A. Polyproline-II helix in proteins: Structure and function. J. Mol. Biol. 2013, 425, 2100-2132. [CrossRef] [PubMed]

200. Curtidor, H.; Patarroyo, M.E.; Patarroyo, M.A. Recent advances in the development of a chemically synthesised anti-malarial vaccine. Expert Opin. Biol. Ther. 2015, 15, 1567-1581. [CrossRef] [PubMed]

201. Sudarsanam, S.; Srinivasan, S. Sequence-dependent conformational sampling using a database of phi(i)+1 and psi(i) angles for predicting polypeptide backbone conformations. Protein Eng. 1997, 10, 1155-1162. [CrossRef] [PubMed]

202. Karpen, M.E.; de Haseth, P.L.; Neet, K.E. Comparing short protein substructures by a method based on backbone torsion angles. Proteins 1989, 6, 155-167. [CrossRef] [PubMed]

203. McGregor, M.J.; Islam, S.A.; Sternberg, M.J. Analysis of the relationship between side chain conformation and secondary structure in globular proteins. J. Mol. Biol. 1987, 198, 295-310. [CrossRef] 
204. Schrauber, H.; Eisenhaber, F.; Argos, P. Rotamers: To be or not to be? An analysis of amino acid side chain conformations in globular proteins. J. Mol. Biol. 1993, 230, 592-612. [CrossRef] [PubMed]

205. Pickett, S.D.; Sternberg, M.J. Empirical scale of side chain conformational entropy in protein folding. J. Mol. Biol. 1993, 231, 825-839. [CrossRef] [PubMed]

206. Doig, A.J.; Sternberg, M.J. Side chain conformational entropy in protein folding. Protein Sci. Publ. Protein Soc. 1995, 4, 2247-2251. [CrossRef] [PubMed]

207. Searle, M.S.; Williams, D.H. The cost of conformational order: Entropy changes in molecular associations. J. Am. Chem. Soc. 1992, 114, 10690-10697. [CrossRef]

208. Nicholls, A.; Sharp, K.A.; Honig, B. Protein folding and association: Insights from the interfacial and thermodynamic properties of hydrocarbons. Proteins 1991, 11, 281-296. [CrossRef] [PubMed]

209. Mandel-Gutfreund, Y.; Zaremba, S.M.; Gregoret, L.M. Contributions of residue pairing to $\beta$-sheet formation: Conservation and covariation of amino acid residue pairs on antiparallel $\beta$-strands. J. Mol. Biol. 2001, 305, 1145-1159. [CrossRef] [PubMed]

210. Narwani, T.J.; Santuz, H.; Shinada, N.; Melarkode Vattekatte, A.; Ghouzam, Y.; Srinivasan, N.; Gelly, J.C.; de Brevern, A.G. Recent advances on polyproline II. Amino Acids 2017, 49, 705-713. [CrossRef] [PubMed]

211. Martin, T.W.; Derewenda, Z.S. The name is bond-H bond. Nat. Struct. Biol. 1999, 6, 403-406. [CrossRef] [PubMed]

212. Pace, C.N.; Fu, H.; Lee Fryar, K.; Landua, J.; Trevino, S.R.; Schell, D.; Thurlkill, R.L.; Imura, S.; Scholtz, J.M.; Gajiwala, K.; et al. Contribution of hydrogen bonds to protein stability. Protein Sci. Publ. Protein Soc. 2014, 23, 652-661. [CrossRef] [PubMed]

213. Roth, C.M.; Neal, B.L.; Lenhoff, A.M. Van der Waals interactions involving proteins. Biophys. J. 1996, 70, 977-987. [CrossRef]

214. Pace, C.N.; Fu, H.; Fryar, K.L.; Landua, J.; Trevino, S.R.; Shirley, B.A.; Hendricks, M.M.; Iimura, S.; Gajiwala, K.; Scholtz, J.M.; et al. Contribution of hydrophobic interactions to protein stability. J. Mol. Biol. 2011, 408, 514-528. [CrossRef] [PubMed]

215. Brandl, M.; Weiss, M.S.; Jabs, A.; Suhnel, J.; Hilgenfeld, R. C-H ... pi-interactions in proteins. J. Mol. Biol. 2001, 307, 357-377. [CrossRef] [PubMed]

216. Dougherty, D.A. The cation-pi interaction. Acc. Chem. Res. 2013, 46, 885-893. [CrossRef] [PubMed]

217. Honig, B.; Yang, A.S. Free energy balance in protein folding. Adv. Protein Chem. 1995, 46, 27-58. [PubMed]

218. Yang, A.S.; Honig, B. Free energy determinants of secondary structure formation: II. Antiparallel $\beta$-sheets. J. Mol. Biol. 1995, 252, 366-376. [CrossRef] [PubMed]

219. Baldwin, R.L. Energetics of protein folding. J. Mol. Biol. 2007, 371, 283-301. [CrossRef] [PubMed]

220. Rose, G.D.; Fleming, P.J.; Banavar, J.R.; Maritan, A. A backbone-based theory of protein folding. Proc. Natl. Acad. Sci. USA 2006, 103, 16623-16633. [CrossRef] [PubMed]

221. Deechongkit, S.; Nguyen, H.; Powers, E.T.; Dawson, P.E.; Gruebele, M.; Kelly, J.W. Context-dependent contributions of backbone hydrogen bonding to $\beta$-sheet folding energetics. Nature 2004, 430, 101-105. [CrossRef] [PubMed]

222. Nick Pace, C.; Scholtz, J.M.; Grimsley, G.R. Forces stabilizing proteins. FEBS Lett. 2014, 588, $2177-2184$. [CrossRef] [PubMed]

223. Herve, M.; Maillere, B.; Mourier, G.; Texier, C.; Leroy, S.; Menez, A. On the immunogenic properties of retro-inverso peptides. Total retro-inversion of T-cell epitopes causes a loss of binding to MHC II molecules. Mol. Immunol. 1997, 34, 157-163. [CrossRef]

224. Lozano, J.M.; Espejo, F.; Ocampo, M.; Salazar, L.M.; Tovar, D.; Barrera, N.; Guzman, F.; Patarroyo, M.E. Mapping the anatomy of a Plasmodium falciparum MSP-1 epitope using pseudopeptide-induced mono- and polyclonal antibodies and CD and NMR conformation analysis. J. Struct. Biol. 2004, 148, 110-122. [CrossRef] [PubMed]

225. Bastian, M.; Lozano, J.M.; Patarroyo, M.E.; Pluschke, G.; Daubenberger, C.A. Characterization of a reduced peptide bond analogue of a promiscuous CD4 T cell epitope derived from the Plasmodium falciparum malaria vaccine candidate merozoite surface protein 1. Mol. Immunol. 2004, 41, 775-784. [CrossRef] [PubMed]

226. Lozano, J.M.; Lesmes, L.P.; Carreno, L.F.; Gallego, G.M.; Patarroyo, M.E. Development of designed site-directed pseudopeptide-peptido-mimetic immunogens as novel minimal subunit-vaccine candidates for malaria. Molecules 2010, 15, 8856-8889. [CrossRef] [PubMed] 
227. Lozano, J.M.; Espejo, F.; Vera, R.; Vargas, L.E.; Rosas, J.; Lesmes, L.; Torres, E.; Cortes, J.; Silva, Y.; Patarroyo, M.E. Protection against malaria induced by chirally modified Plasmodium falciparum's MSP-1 42 pseudopeptides. Biochem. Biophys. Res. Commun. 2005, 329, 1053-1066. [CrossRef] [PubMed]

228. Patarroyo, M.E.; Cifuentes, G.; Martinez, N.L.; Patarroyo, M.A. Atomic fidelity of subunit-based chemically-synthesized antimalarial vaccine components. Prog. Biophys. Mol. Biol. 2010, 102, 38-44. [CrossRef] [PubMed]

229. Patarroyo, M.E.; Cifuentes, G.; Pirajan, C.; Moreno-Vranich, A.; Vanegas, M. Atomic evidence that modification of H-bonds established with amino acids critical for host-cell binding induces sterile immunity against malaria. Biochem. Biophys. Res. Commun. 2010, 394, 529-535. [CrossRef] [PubMed]

230. Tolia, N.H.; Enemark, E.J.; Sim, B.K.; Joshua-Tor, L. Structural basis for the EBA-175 erythrocyte invasion pathway of the malaria parasite Plasmodium falciparum. Cell 2005, 122, 183-193. [CrossRef] [PubMed]

231. Torres, M.H.; Salazar, L.M.; Vanegas, M.; Guzman, F.; Rodriguez, R.; Silva, Y.; Rosas, J.; Patarroyo, M.E. Modified merozoite surface protein-1 peptides with short alpha helical regions are associated with inducing protection against malaria. Eur. J. Biochem. FEBS 2003, 270, 3946-3952. [CrossRef]

232. Cifuentes, G.; Patarroyo, M.E.; Urquiza, M.; Ramirez, L.E.; Reyes, C.; Rodriguez, R. Distorting malaria peptide backbone structure to enable fitting into MHC class II molecules renders modified peptides immunogenic and protective. J. Med. Chem. 2003, 46, 2250-2253. [CrossRef] [PubMed]

233. Suarez, J.E.; Urquiza, M.; Puentes, A.; Garcia, J.E.; Curtidor, H.; Ocampo, M.; Lopez, R.; Rodriguez, L.E.; Vera, R.; Cubillos, M.; et al. Plasmodium falciparum circumsporozoite (CS) protein peptides specifically bind to HepG2 cells. Vaccine 2001, 19, 4487-4495. [CrossRef]

234. Bermudez, A.; Vanegas, M.; Patarroyo, M.E. Structural and immunological analysis of circumsporozoite protein peptides: A further step in the identification of potential components of a minimal subunit-based, chemically synthesised antimalarial vaccine. Vaccine 2008, 26, 6908-6918. [CrossRef] [PubMed]

235. Pinheiro, S.; Soteras, I.; Gelpi, J.L.; Dehez, F.; Chipot, C.; Luque, F.J.; Curutchet, C. Structural and energetic study of cation-pi-cation interactions in proteins. Phys. Chem. Chem. Phys. PCCP 2017, 19, 9849-9861. [CrossRef] [PubMed]

236. Ma, J.C.; Dougherty, D.A. The Cationminus signpi Interaction. Chem. Rev. 1997, 97, 1303-1324. [CrossRef] [PubMed]

237. Salonen, L.M.; Ellermann, M.; Diederich, F. Aromatic rings in chemical and biological recognition: Energetics and structures. Angew. Chem. Int. Ed. Engl. 2011, 50, 4808-4842. [CrossRef] [PubMed]

238. Waters, M.L. Aromatic interactions in peptides: Impact on structure and function. Biopolymers 2004, 76, 435-445. [CrossRef] [PubMed]

239. Sunner, J.; Nishizawa, K.; Kebarle, P. Ion-solvent molecule interactions in the Gas Phase. The potassium ion and benzene. J. Phys. Chem. 1981, 85, 1814-1820. [CrossRef]

240. Dougherty, D.A. Cation-pi interactions in chemistry and biology: A new view of benzene, Phe, Tyr, and Trp. Science 1996, 271, 163-168. [CrossRef] [PubMed]

241. Burley, S.K.; Petsko, G.A. Aromatic-aromatic interaction: A mechanism of protein structure stabilization. Science 1985, 229, 23-28. [CrossRef] [PubMed]

242. Burley, S.K.; Petsko, G.A. Amino-aromatic interactions in proteins. FEBS Lett. 1986, 203, 139-143. [CrossRef]

243. Burley, S.K.; Petsko, G.A. Dimerization energetics of benzene and aromatic amino acid side chains. J. Am. Chem. Soc. 1986, 108, 7995-8001. [CrossRef]

244. Burley, S.K.; Petsko, G.A. Weakly polar interactions in proteins. Adv. Protein Chem. 1988, 39, $125-189$. [PubMed]

245. Jackson, M.R.; Beahm, R.; Duvvuru, S.; Narasimhan, C.; Wu, J.; Wang, H.N.; Philip, V.M.; Hinde, R.J.; Howell, E.E. A preference for edgewise interactions between aromatic rings and carboxylate anions: The biological relevance of anion-quadrupole interactions. J. Phys. Chem. B 2007, 111, 8242-8249. [CrossRef] [PubMed]

246. Frontera, A.; Gamez, P.; Mascal, M.; Mooibroek, T.J.; Reedijk, J. Putting anion-pi interactions into perspective. Angew. Chem. Int. Ed. Engl. 2011, 50, 9564-9583. [CrossRef] [PubMed]

247. Perutz, M.F. The chemistry of biological molecular recognition-The role of aromatic rings as hydrogen-bond acceptors in molecular recognition. Philos. Trans. R. Soc. Phys. Eng. Sci. 1993, 345, 105-112. [CrossRef]

248. Nishio, M. CH/ $\pi$ hydrogen bonds in crystals. CristEngComm 2004, 6, 130-158. [CrossRef] 
249. Zondlo, N.J. Aromatic-proline interactions: Electronically tunable CH/ $\pi$ interactions. Acc. Chem. Res. 2013, 46, 1039-1049. [CrossRef] [PubMed]

250. Kumar, M.; Balaji, P.V. C-H . . p pi interactions in proteins: Prevalence, pattern of occurrence, residue propensities, location, and contribution to protein stability. J. Mol. Model. 2014, 20, 2136. [CrossRef] [PubMed]

251. Riley, K.E.; Hobza, P. Noncovalent interactions in biochemistry. Comp. Mol. Sci. 2011, 1, 3-17. [CrossRef]

252. Patarroyo, M.E.; Cifuentes, G.; Rodriguez, R. Structural characterisation of sporozoite components for a multistage, multi-epitope, anti-malarial vaccine. Int. J. Biochem. Cell Biol. 2008, 40, 543-557. [CrossRef] [PubMed]

253. Reyes, C.; Moreno-Vranich, A.; Patarroyo, M.E. The role of pi-interactions and hydrogen bonds in fully protective synthetic malaria vaccine development. Biochem. Biophys. Res. Commun. 2017, 484, 501-507. [CrossRef] [PubMed]

254. Holland, C.J.; Cole, D.K.; Godkin, A. Re-Directing CD4(+) T Cell Responses with the Flanking Residues of MHC Class II-Bound Peptides: The Core is Not Enough. Front. Immunol. 2013, 4, 172. [CrossRef] [PubMed]

255. Arnold, P.Y.; La Gruta, N.L.; Miller, T.; Vignali, K.M.; Adams, P.S.; Woodland, D.L.; Vignali, D.A. The majority of immunogenic epitopes generate CD4+ T cells that are dependent on MHC class II-bound peptide-flanking residues. J. Immunol. 2002, 169, 739-749. [CrossRef] [PubMed]

256. Conant, S.B.; Swanborg, R.H. MHC class II peptide flanking residues of exogenous antigens influence recognition by autoreactive T cells. Autoimmun. Rev. 2003, 2, 8-12. [CrossRef]

257. Nelson, C.A.; Petzold, S.J.; Unanue, E.R. Identification of two distinct properties of class II major histocompatibility complex-associated peptides. Proc. Natl. Acad. Sci. USA 1993, 90, 1227-1231. [CrossRef] [PubMed]

258. Nelson, C.A.; Petzold, S.J.; Unanue, E.R. Peptides determine the lifespan of MHC class II molecules in the antigen-presenting cell. Nature 1994, 371, 250-252. [CrossRef] [PubMed]

259. Nelson, C.A.; Roof, R.W.; McCourt, D.W.; Unanue, E.R. Identification of the naturally processed form of hen egg white lysozyme bound to the murine major histocompatibility complex class II molecule I-Ak. Proc. Natl. Acad. Sci. USA 1992, 89, 7380-7383. [CrossRef] [PubMed]

260. Nelson, C.A.; Viner, N.J.; Young, S.P.; Petzold, S.J.; Unanue, E.R. A negatively charged anchor residue promotes high affinity binding to the MHC class II molecule I-Ak. J. Immunol. 1996, 157, 755-762. [PubMed]

261. Carson, R.T.; Vignali, K.M.; Woodland, D.L.; Vignali, D.A. T cell receptor recognition of MHC class II-bound peptide flanking residues enhances immunogenicity and results in altered TCR V region usage. Immunity 1997, 7, 387-399. [CrossRef]

262. Moudgil, K.D.; Sercarz, E.E.; Grewal, I.S. Modulation of the immunogenicity of antigenic determinants by their flanking residues. Immunol. Today 1998, 19, 217-220. [CrossRef]

263. Godkin, A.J.; Smith, K.J.; Willis, A.; Tejada-Simon, M.V.; Zhang, J.; Elliott, T.; Hill, A.V. Naturally processed HLA class II peptides reveal highly conserved immunogenic flanking region sequence preferences that reflect antigen processing rather than peptide-MHC interactions. J. Immunol. 2001, 166, 6720-6727. [CrossRef] [PubMed]

264. Lovitch, S.B.; Pu, Z.; Unanue, E.R. Amino-terminal flanking residues determine the conformation of a peptide-class II MHC complex. J. Immunol. 2006, 176, 2958-2968. [CrossRef] [PubMed]

265. Cole, D.K.; Gallagher, K.; Lemercier, B.; Holland, C.J.; Junaid, S.; Hindley, J.P.; Wynn, K.K.; Gostick, E.; Sewell, A.K.; Gallimore, A.M.; et al. Modification of the carboxy-terminal flanking region of a universal influenza epitope alters CD4(+) T-cell repertoire selection. Nat. Commun. 2012, 3, 665. [CrossRef] [PubMed]

266. Reyes, C.; Rojas-Luna, R.; Aza-Conde, J.; Tabares, L.; Patarroyo, M.A.; Patarroyo, M.E. Critical role of HLA-DR $\beta^{*}$ binding peptides' peripheral flanking residues in fully-protective malaria vaccine development. Biochem. Biophys. Res. Commun. 2017, 489, 339-345. [CrossRef] [PubMed]

267. Gross, A.; Hashimoto, C.; Sticht, H.; Eichler, J. Synthetic Peptides as Protein Mimics. Front. Bioeng. Biotechnol. 2015, 3, 211. [PubMed]

Sample Availability: Samples of the compounds cHABPs and mHABPs are available from the authors. 